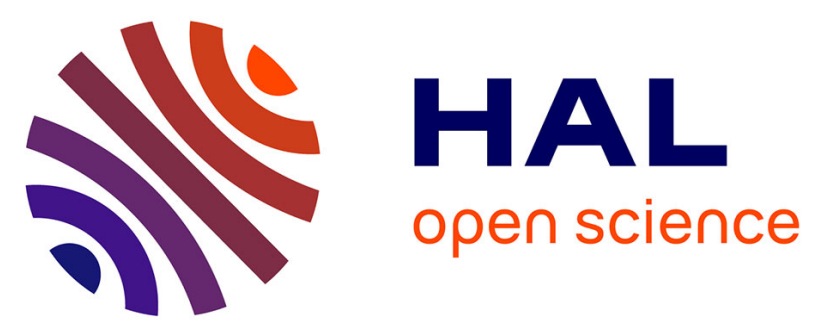

\title{
Cyclostratigraphy and Magnetostratigraphy of the Middle Miocene Ashigong Formation, Guide Basin, China, and Its Implications for the Paleoclimatic Evolution of NE Tibet \\ Zhixiang Wang, Yongjin Shen, Alexis Licht, Chunju Huang
}

\section{To cite this version:}

Zhixiang Wang, Yongjin Shen, Alexis Licht, Chunju Huang. Cyclostratigraphy and Magnetostratigraphy of the Middle Miocene Ashigong Formation, Guide Basin, China, and Its Implications for the Paleoclimatic Evolution of NE Tibet. Paleoceanography and Paleoclimatology, 2018, 33 (10), pp.1066

- 1085. 10.1029/2018pa003409. hal-03469345

\section{HAL Id: hal-03469345 \\ https://hal.science/hal-03469345}

Submitted on 7 Dec 2021

HAL is a multi-disciplinary open access archive for the deposit and dissemination of scientific research documents, whether they are published or not. The documents may come from teaching and research institutions in France or abroad, or from public or private research centers.
L'archive ouverte pluridisciplinaire HAL, est destinée au dépôt et à la diffusion de documents scientifiques de niveau recherche, publiés ou non, émanant des établissements d'enseignement et de recherche français ou étrangers, des laboratoires publics ou privés. 


\section{Paleoceanography and Paleoclimatology}

\section{RESEARCH ARTICLE}

10.1029/2018PA003409

Zhixiang Wang and Yongjin Shen contributed equally.

Key Points:

- The Guide Basin was a hydrologically closed lake from at least 14.4 to $10 \mathrm{Ma}$ that attained a maximum extent between $\sim 11.4$ and $10.5 \mathrm{Ma}$

- Maximum lake expansion was coeval to a known peak of monsoonal intensity

- Lake expansion displayed cyclic variations following $~ 100-k y r$ orbital cycles and weaker $\sim 41-$ kyr cycles

Correspondence to:

C. Huang,

huangcj@cug.edu.cn

Citation:

Wang, Z., Shen, Y., Licht, A., \& Huang, C. (2018). Cyclostratigraphy and

magnetostratigraphy of the middle Miocene Ashigong formation, Guide Basin, China, and its implications for the paleoclimatic evolution of NE Tibet. Paleoceanography and

Paleoclimatology, 33. https://doi.org/ 10.1029/2018PA003409

Received 23 MAY 2018 Accepted 16 SEP 2018 Accepted article online 19 SEP 2018

\section{Cyclostratigraphy and Magnetostratigraphy of the Middle Miocene Ashigong Formation, Guide Basin, China, and Its Implications for the Paleoclimatic Evolution of NE Tibet}

\author{
Zhixiang Wang ${ }^{1} \mathbb{D}$, Yongjin Shen ${ }^{2}$, Alexis Licht ${ }^{2} \mathbb{D}$, and Chunju Huang' 1 \\ ${ }^{1}$ State Key Laboratory of Biogeology and Environmental Geology, School of Earth Sciences, China University of \\ Geosciences, Wuhan, China, ${ }^{2}$ Department of Earth and Space Sciences, University of Washington, Seattle, WA, USA
}

\begin{abstract}
Recent tectonostratigraphy studies have shown that Northeast Tibet underwent significant tectonic uplift and basin partitioning at 13-8 Ma. This time window is also a period of significant changes in Asian monsoonal intensity, mechanisms of which remain poorly understood. Though many studies have tried to decipher paleoclimatic trends from sedimentary archives in Northeast Tibetan basins, it is often hard to distinguish local orographic effects from regional climate changes in such a tectonically active context. Here we investigated the sedimentary record of the Ashigong Formation, Guide Basin, in order to better constrain the Tibetan paleoenvironmental evolution and link it to uplift episodes and monsoonal evolution. By studying the lithology, magnetostratigraphy, redness, magnetic susceptibility, and elemental content of a 500-m section, we show that the Ashigong Formation was deposited in a saline paleolake between 14.4 and $10 \mathrm{Ma}$. Lake expansion displayed cyclic variations following 100-kyr cycles and weaker $\sim 41-k y r$ cycles, reaching its maximum between $\sim 11.4$ and 10.5 Ma. Our results show that the Guide Basin was hydrologically closed from most of the middle Miocene, confirming previous studies that proposed an early Miocene partitioning of this basin. The maximum lake expansion between 11.4 and $10.5 \mathrm{Ma}$ is coeval to a known peak of monsoonal intensity. This, and the evidence for a strong orbital control on lake expansion, supports a strong monsoonal control on the expansion of middle Miocene Tibet paleolakes. The origin of the $\sim 100-\mathrm{kyr}$ forcing on monsoonal moisture supply—different from Quaternary forcing-questions the climatic mechanism of these middle Miocene monsoons and suggests that westerly derived moisture might have also significantly contributed to the regional hydrological budget.
\end{abstract}

\section{Introduction}

Northeast Tibet lies at the transition zone between the central Asian desertic belts and the wetter, monsoonal areas of Eastern China. Its hydrological budget is a balance of summer monsoonal moisture coming from the Pacific Ocean and the South China Sea across eastern China, and winter, westerly derived moisture from central Asia (Bookhagen et al., 2005; Caves et al., 2015; Tian et al., 2007). Summer monsoonal rainfall composes up to $70 \%$ of the annual rainfall (Miao et al., 2014), but this contribution might have been reduced during past intervals of weaker monsoonal activity (Sun \& Windley, 2015; Zhang et al., 2012). The past hydrological budget recorded in NE Tibetan sedimentary basins can be used to document the penetration of monsoonal moisture into central China and decipher the evolution of the East Asian monsoon in deep time (Nie et al., 2017).

Numerous paleoclimatic studies have emphasized that the late middle Miocene was a period of climatic turnover in East and Central Asia. Palynological records from the Tianshui Basin (Hui et al., 2011; Liu et al., 2016), Liupan Mountains (Jiang \& Ding, 2008), western Qaidam Basin (Miao et al., 2011), and northern Tian Shan (Tang et al., 2011) show that the pollen representing drought-tolerant plants significantly increased and became the dominant taxa in most assemblages, indicating persistent drier conditions in central Asia. A rapid decrease of magnetic susceptibility (MS) between 11.5 and 10.3 Ma within the Neogene eolian sequences of the eastern Xorhol Basin at the northern edge of the Tibetan Plateau revealed enhanced aridification at that time (Li et al., 2014). A 1,000-m Neogene sedimentary sequence (from 17 to $5.0 \mathrm{Ma}$ ) in the western Qaidam Basin displays a sharp decrease of carbonate content since 11-Ma corroborating increased regional aridity (Song et al., 2014). Isotopic data from pedogenic and lacustrine carbonates in the northeastern (NE) Qaidam Basin displays a positive shift of $\sim 2.5 \%$ in $\delta^{18} \mathrm{O}$ values from 12 to $10.7 \mathrm{Ma}$, also indicating 
intensified aridity (Zhuang et al., 2011). Similarly, multiple proxies (including MS, pollen, redness, and total inorganic carbon) applied on the Sikouzi section of the Ningxia province indicate a substantial change after 12-11 Ma and corroborate an increase in regional aridity at that time (Jiang et al., 2008).

A comprehensive review of numerous proxies from the South China Sea sediments reveals a strengthening of the East Asian summer monsoon during approximately 21-18 Ma, followed by an extended period of monsoon maximum from 18 to $10 \mathrm{Ma}$, with a peak around $11 \mathrm{Ma}$, followed by abrupt monsoonal weakening (Clift et al., 2008, 2014), potentially in response to global cooling (Jiang \& Ding, 2008). By contrast, another study has proposed that the East Asian summer monsoon intensity has rather decreased gradually from its maximum since the early Miocene (Wan et al., 2010).

Deciphering the origin of the late middle Miocene increase in aridity and its link to monsoonal activity and global cooling remain challenging. The uplift of the Tibetan Plateau-blocking moisture-bearing windscould have played an important role in the strengthening of aridification in central Asia (Miao et al., 2012). Climatic simulations show that the uplift of the northern Tibet enhanced the desertification of inland Asia and simultaneously strengthened the East Asian winter monsoon (Liu et al., 2015; Tang et al., 2013). But individual uplift episodes of the many local ranges at the edge of NE Tibet (Qilian Shan, Laji Shan, and Kunlun Shan) could have created local orographic barriers and enhanced aridity locally. Moreover, decrease of atmospheric $\mathrm{CO}_{2}$ following the Middle Miocene Climatic Optimum (Tripati et al., 2009) may have also played an important factor in Asian aridification.

Refining the timing of Asian aridification and moisture supply variation in individual basins is critical to understand the importance of continent-wide effects on local aridity (monsoonal variations linked to global cooling or uplift) versus regional effects (uplift of local ranges). NE Tibet is today divided into several individual sedimentary basins, namely, the Guide, Xining, Linxia, Xunhua, and Qaidam Basins (Figure 1; Hough et al., 2011, 2014). Numerous studies have shown increased uplift and exhumation in NE Tibet since the early Miocene, resulting in the partitioning of these basins and the formation of a set of individual, closed lake systems that lasted until the late Miocene (Fang et al., 2005; Hough et al., 2011, 2014; Lease et al., 2007; Liu et al., 2007, 2013). Whereas the past evolution of lake level could provide insights into potential trends in regional aridity, the origin and history of these lakes remain poorly dated and documented.

The Guide Basin provides a relatively continuous sedimentary record since at least the Eocene, but only the late Miocene-Pliocene units have been precisely dated (Fang et al., 2005; Pares et al., 2003). Our paper focuses on the middle Miocene Ashigong Formation of the Guide Basin. We provided sedimentological observations and magnetostratigraphic dating of a 510-m composite section, with redness, MS and elemental composition of a 370-m portion of the section in order to decipher the evolution and chronology of the basin hydrology. Our results show that the maximum extent of the paleolake in Guide Basin at 11.4-10.5 Ma is coeval to peak of monsoonal intensity but that lake expansion was mainly controlled by eccentricity forcing, at odds with Quaternary summer monsoon dynamics.

\section{Geological Setting}

The Guide Basin is one of the numerous Cenozoic sedimentary basins occupying the NE Tibetan Plateau and is adjacent to the Xining, Xunhua, and Gonghe Basins (Figure 1). Originally, these basins were parts of the same retro-arc foreland basin but were later partitioned into individual basins, today enclosed by numerous mountain ranges: the North Qilian to the north, the Kunlun Shan to the south, Ela Shan to the west, and Liupan Shan to the east (Lease et al., 2012; Liu et al., 2013). Initial uplift of some of these ranges is dated to the early Eocene ( 55-45 Ma), shortly after the onset of the Indo-Asian collision (Clark et al., 2010; He et al., 2017; Wang et al., 2017), but most of the basin partitioning has been shown to be Neogene (Hough et al., 2014; Lease, 2014), with deformation north of the West Qinling Mountains beginning during the early Miocene (Hough et al., 2014; Liu et al., 2013). Low-temperature thermochronology and provenance studies have shown an onset of uplift of the Laji Shan approximately 22 Ma (Lease et al., 2011, 2012) separating the Xining Basin from the Xunhua and Linxia Basins. During the early Miocene, the uplift of the Zamazari Shan initiated the separation between the Guide Basin and the Xunhua Basin to the east (Hough et al., 2014). A change of the kinematic style of the Tibetan Plateau growth occurred during the late Middle Miocene at approximately $13 \mathrm{Ma}$, with deformation previously dominated by a long-standing NNE-SSW contraction incorporating new E-W structures (Lease, 2014; Lease et al., 2011). The onset of uplift of the Jishi Shan 

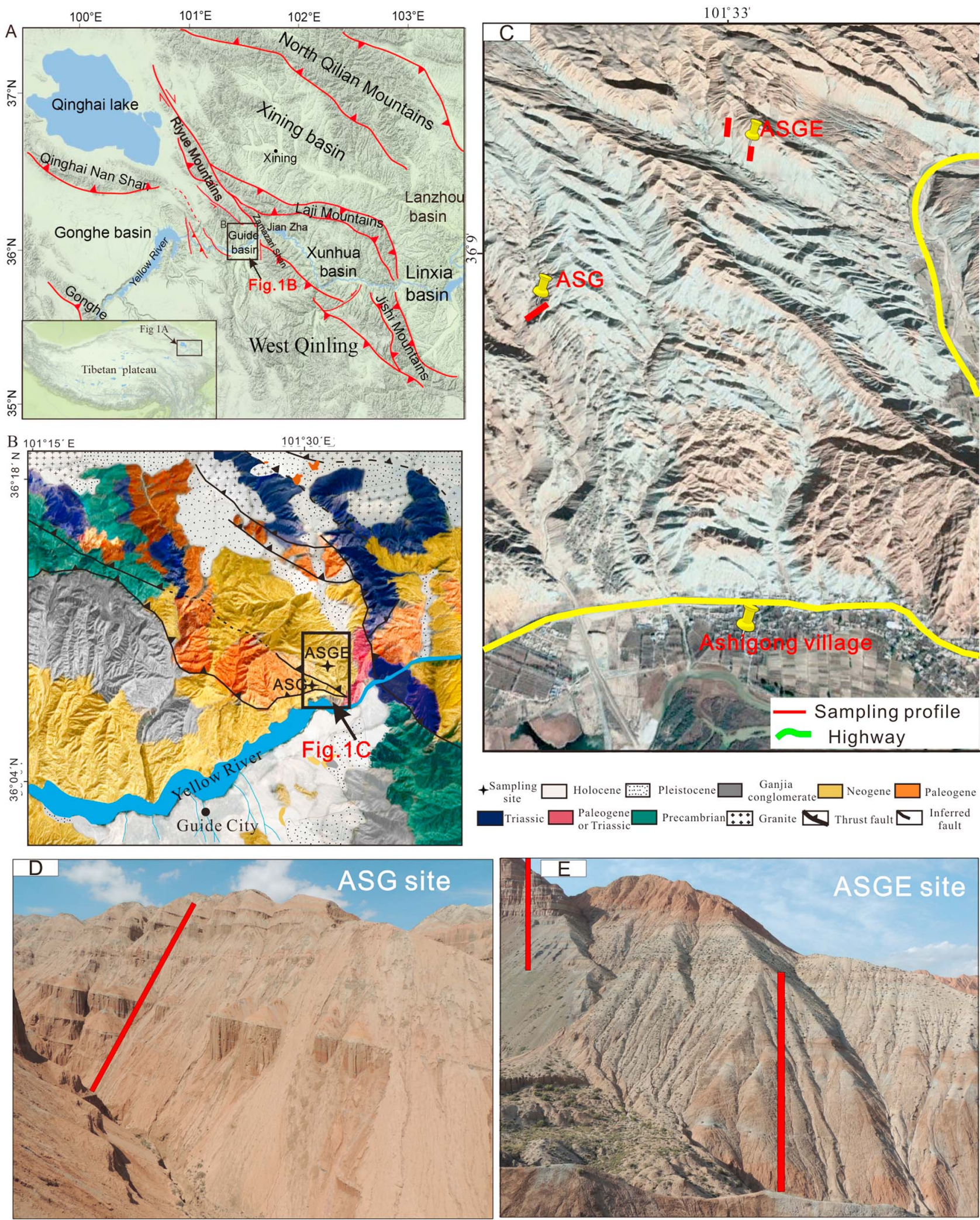

Figure 1. (a) Simplified tectonic map of the northeastern Tibetan plateau showing the major blocks, regional basins and large faults, after Liu et al. (2013) and Hough et al. (2014). (b) Geological map of the studied area showing the location of the sampling sites and regional lithology, modified from Fang et al. (2005) and Liu et al. (2013). The sampling site is near the town of Ashigong village. (c) Detailed location of the different sections measured in this paper (basemap from Google earth). (d) and (e) are field pictures presenting the sampling profiles (red columns) of the ASG and ASGE sites, respectively. ASG = Ashigong; ASGE $=$ Ashigong east. 
occurred during this period, as inferred from low-temperature thermochronology of the Jishi Shan thrust (Lease et al., 2011), detrital zircon U-Pb ages (Lease et al., 2012) and local climate change indicated by stable isotope data (Hough et al., 2011, 2014; Lease et al., 2011, 2012).

The Guide Basin, with elevations ranging from 2,200 $\mathrm{m}$ to about 3,600 m, is bounded by the Waligong Shan to the west, Zamazari Shan to the east, the Laji Shan to the north, and the West Qinling Mountains to the south (Figure 1a). The structures developed in the Cenozoic strata of the Guide Basin are controlled by six prominent south-verging thrust faults (Fang et al., 2005). The oldest deposits in the Guide Basin consist of the poorly studied Eocene Gepiza Formation and the Oligocene Xiagarang Formation, dominated by orange-red sandy gravel, sandstones, siltstones, and mudstones (Liu et al., 2013; Wang et al., 2016; Figure 2). The Neogene strata of Guide Basin have been subdivided into five units based on lithology (Figure 2): the Guidemen (20.8-19 Ma), Garang (19-<16 Ma), Ashigong ( $>11.5-7.8 \mathrm{Ma})$, Heerjia (7.83.6 Ma), Ganjia (3.6- 2.6 Ma), and Amigang ( 2.6-1.8 Ma) formations (Figure 2). The youngest of these units (upper Ashigong to Amigang Formations) have been dated by a combination of paleomagnetism and mammalian stratigraphy (Fang et al., 2005), whereas older units only benefit from biostratigraphic dating based on mammalian fauna (Gu et al., 1992; Song et al., 2001). Only the upper part of the Ashigong Formation has been dated by magnetostratigraphy (Fang et al., 2005), and the age of its lower parts remains unknown.

The sedimentological history of these Neogene strata has been extensively described by Song et al. (2001) and Fang et al. (2005): The lower and middle Miocene units (Guidemen and Garang Formations) are dominated by conglomerates and coarse cross-bedded sandstones reflecting alluvial fans and associated distal braided stream to fan systems (Figure 2) that mark the onset of uplift of the surrounding ranges and partitioning of the NE Tibetan basins. The late middle Miocene Ashigong Formation is marked by the alternation of red beds with pedogenic features and finely laminated grayish-green mudstones with rare sandstones; the lack of coarse-grained clasts, lag deposits, and pedogenic features and occurrence of horizontal laminations in most of green mudstones and marls in Ashigong Formation suggest that these sediments were deposited in a lacustrine setting (Hough et al., 2014). The late Miocene-Pliocene Heerjia and Ganjia Formations reflect a return to alluvial fan deposition with coarse sandstones, conglomerates, and paleosols. They are unconformably overlain by the early Pleistocene Amigang Formation, dominated by finely laminated siltstones and mudstones, reflecting the establishment of a shallow lake (Fang et al., 2005). These lithological variations of the Guide Basin can be spatially correlated with those observed in the nearby Xunhua and Linxia Basins (Figure 2; Hough et al., 2014).

\section{Methods}

A 510 -m-thick composite section near the Ashigong village $\left(36.14^{\circ} \mathrm{N}, 101.54^{\circ} \mathrm{E}\right.$; Figure $\left.1 \mathrm{C}\right)$ in the southern foothills of the Laji Mountains was described and sampled based on two subsections at two localities: ASG for the first $295 \mathrm{~m}$ of our measured section and ASGE for remaining part (Figure 1c). Sampling trenches were excavated to a depth of $>0.5 \mathrm{~m}$ from the freshly exposed surfaces for sedimentary logging and sampling. The strata are dominated by alternating red beds and finely laminated gray mudstones attributed to the Ashigong Formation (see section 2 for detailed descriptions).

\subsection{Paleomagnetic Analysis}

A total of 447 oriented block samples were collected for paleomagnetic investigation with an average sampling step of 1-2 m along our composite section. At each sampling site, at least two oriented cubic samples $(2 \times 2 \times 2 \mathrm{~cm})$ were obtained. The 104 oriented block samples from the lower section $(0-140 \mathrm{~m})$ were analyzed for magnetization at the paleomagnetic laboratory of the Institute of Earth Environment, Chinese Academy of Sciences (Xi'an) using a 2 G cryogenic superconducting magnetometer (model 755R) housed in a magnetic shielded space $(<150 \mathrm{nT})$. All these samples underwent stepwise thermal demagnetization that included 14 steps with intervals of $50-100^{\circ} \mathrm{C}$ below $500^{\circ} \mathrm{C}$ and $20-25^{\circ} \mathrm{C}$ above (up to $680^{\circ} \mathrm{C}$ ). Three hundred forty-three oriented block samples from the middle and upper section (140-510 $\mathrm{m}$ ) were measured using a 2G-755-4K superconducting magnetometer in a magnetically shielded room at the Laboratory for Paleomagnetism and Environmental Magnetism, China University of Geosciences (Beijing). Thermal demagnetization of these samples included a maximum of 18 steps with intervals of $50{ }^{\circ} \mathrm{C}$ below $500{ }^{\circ} \mathrm{C}$ and $15-$ $25^{\circ} \mathrm{C}$ above to $680^{\circ} \mathrm{C}$. The two types of superconducting magnetometers used in this study were used 


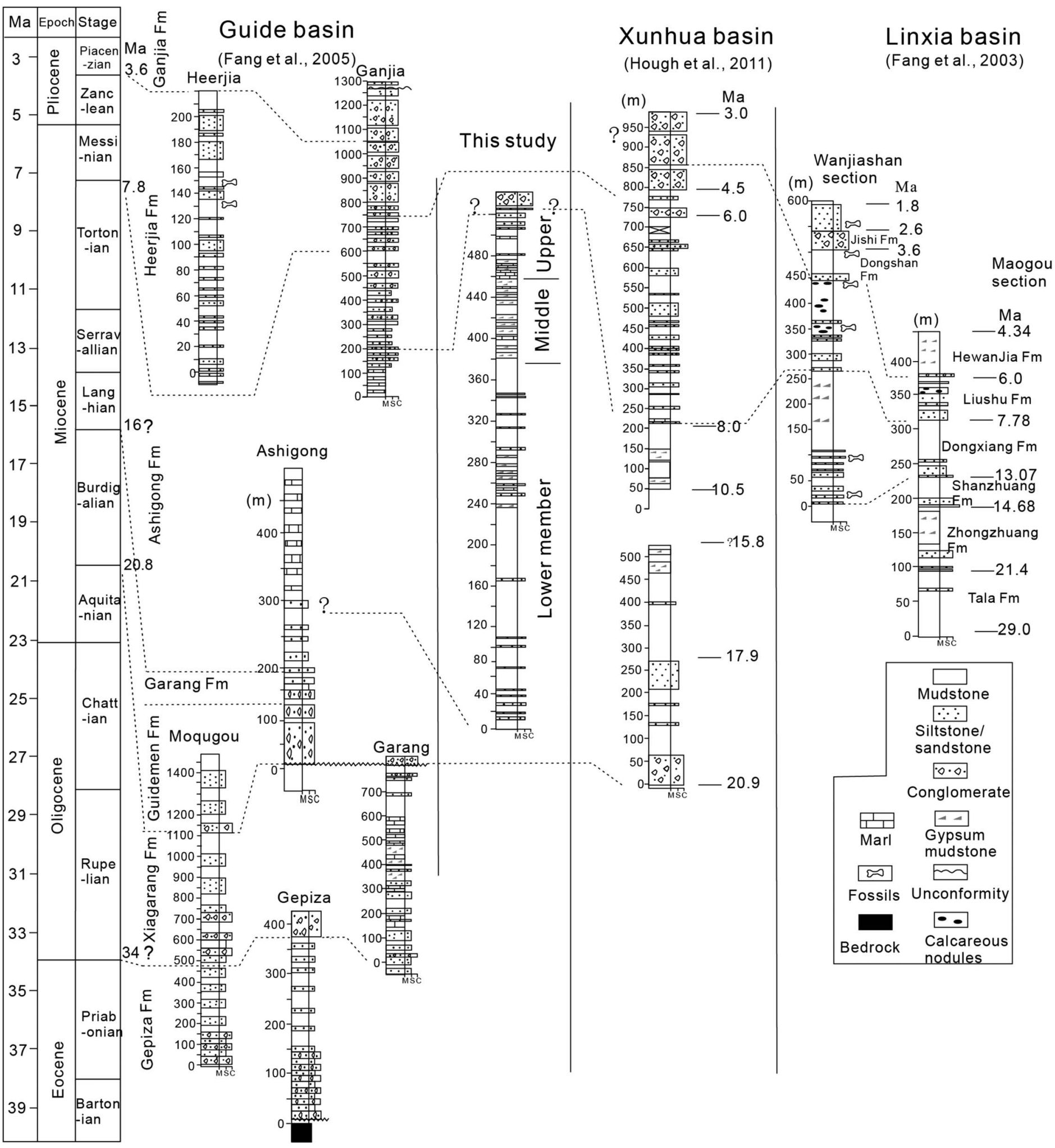

Figure 2. Stratigraphy and lithology in Guide Basin, after Wang, Song, et al. (2016), and its correlation with the Xunhua and Linxia Basin, after Hough et al. (2014), with international chronostratigraphic framework in the leftmost (Ogg et al., 2016). The depositional ages of the Guide, Xunhua and Linxia Basins are based on paleomagnetic studies by Fang et al. (2005), Hough et al. (2011), and Fang et al. (2003), respectively. Grain size abbreviations: $M=$ mudstone; $S=$ sandstone/siltstone; $\mathrm{C}=$ conglomerate. 
with similar parameters. The measurement range of 2G-755-4K at China University of Geosciences (Beijing) is $1.0 \times 10^{-12}$ to $2.0 \times 10^{-4} \mathrm{~A} \cdot \mathrm{m}^{2}$ with sensitivity of $1 \times 10^{-12} \mathrm{~A} \cdot \mathrm{m}^{2}$, and $755 \mathrm{R} \mathrm{U}$-channel at the Chinese Academy of Sciences (Xi'an) is $2.0 \times 10^{-12}$ to $2.0 \times 10^{-4} \mathrm{~A} \cdot \mathrm{m}^{2}$ with sensitivity of $2.0 \times 10^{-12} \mathrm{~A} \cdot \mathrm{m}^{2}$. Temperature heating all used a TD-48 thermal demagnetizer. The characteristic remanent magnetization (ChRM) was determined by principal component analysis for each sample using the PaleoMag software of Jones (2002).

\subsection{Spectral Analysis}

We measured the redness $\left(a^{*}\right)$, the MS, and the composition in iron ( $\left.\mathrm{Fe}\right)$, calcium (Ca), and strontium ( $\mathrm{Sr}$ ) along our composite section. These proxies have been extensively used to interpret paleoenvironmental trends and cycles in terrestrial sediments (An et al., 2001; Kemp \& Coe, 2007; Xiao et al., 2010). A total of 3,700 samples were collected at about every $10 \mathrm{~cm}$ from the 140- to 510-m intervals. Samples were ground into powder and passed through 200-mesh sieve. Each powder sample was scanned five times using a Microtek ScanMaker S260 flatbed color scanner. Digital images (3,200×6,400-dpi optical resolution) of powder samples were transformed to a CLE LAB color model using ImageJ software (Abràmoff et al., 2004). The MS (quantified by $\kappa$, the volume susceptibility) of powder samples was measured with a Bartington MS3 Magnetic Susceptibility System. Chemical compositions were analyzed using an Innov-X Systems X-ray fluorescence spectrometer in geochemistry mode using beam 1 (50 kv) and beam 2 (10 kv).

The $\mathrm{a}^{*}$ (redness) series of 140 to $380 \mathrm{~m}$ and $460-510 \mathrm{~m}$ were prewhitened in Kaleidagraph software by subtracting $50 \%$ and $10 \%$ weighted averages, a common method to remove long-term trends, (Cleveland, 1979). Spectral analysis of the 380- to 460-m interval was carried out without subtracting anything weighted averages because of the absence of any visual inconspicuous long-term trend in the signal. Then, a sliding window spectral analysis was carried out by evolutive Fast Fourier transform spectrograms with evofft.m software (Kodama \& Hinnov, 2014) to detect variability in accumulation rates and hiatuses (Kodama \& Hinnov, 2014; Li et al., 2016). Based on the paleomagnetic results and calculated accumulation rates, the dominant spectral components (short and long eccentricity cycles, obliquity, and precession cycles) were extracted using the Gauss band-pass filtering in the software AnalySeries 2.0.8 software (Paillard et al., 1996). The power spectra of the untuned and tuned data were analyzed by the $2 \pi$ MultiTaper Method using the Singular Spectrum Analysis-MultiTaper Method Toolkit with robust red noise models at the mean, 90\%, 95\%, and 99\% confidence levels (Mann \& Lees, 1996).

\section{Results}

\subsection{Sedimentological Observations}

Based on lithologic changes, we divided the studied sections of the Ashigong Formation into three members: lower, middle, and upper members.

The basal portion of the lower member $(0-295 \mathrm{~m})$ is characterized by massive red-brown, blocky mudstones interbedded with grayish-green, finely laminated mudstones, sandstone, and siltstone. The grayish-green mudstones contain abundant interstitial gypsum, isolated gypsum crystals, and gypsum veins (Figure 3a); and the content of gypsum increases upward. The upper portion of the lower member (295-380 m) is dominated by massive red-brown mudstones interbedded with some grayish-green mudstone and sandstone and with gypsum layers and gypsum veins in grayish-green mudstone layers (Figure 3b). Massive red-brown mudstones are 10-20 m thick and laterally continuous over thousands of meters. Grayish-green mudstones are 3-10 m thick and laterally continuous over thousands of meters. Gypsum layers are only found in green mudstones, with about 0.2 to $10 \mathrm{~cm}$ thick and laterally continuous over $100 \mathrm{~m}$. Gypsum cystals can be found in both red-brown and green layers, in the shape of flowers, flakes or foliated. The grayish-green mudstone between 307 and $323 \mathrm{~m}$ has some light-yellow mudstone with foliated gypsum crystals.

The middle member (380-455 m) mainly consists of marls and gypsum-rich grayish-green mudstones, with only rare layers of red-brown mudstones, sandstones, and laminated siltstone (Figure 3b). Gypsum layers throughout the grayish-green layers are very thin with no more than $10 \mathrm{~cm}$ and laterally continuous over $100 \mathrm{~m}$. The grayish-green layers have abundant gypsum crystals.

The upper member (455-508 $\mathrm{m}$ ) is very similar to the lower member and consists of prominent dense red-brown and grayish-green mudstone interbedded with rare grayish-green laminated sandstones 

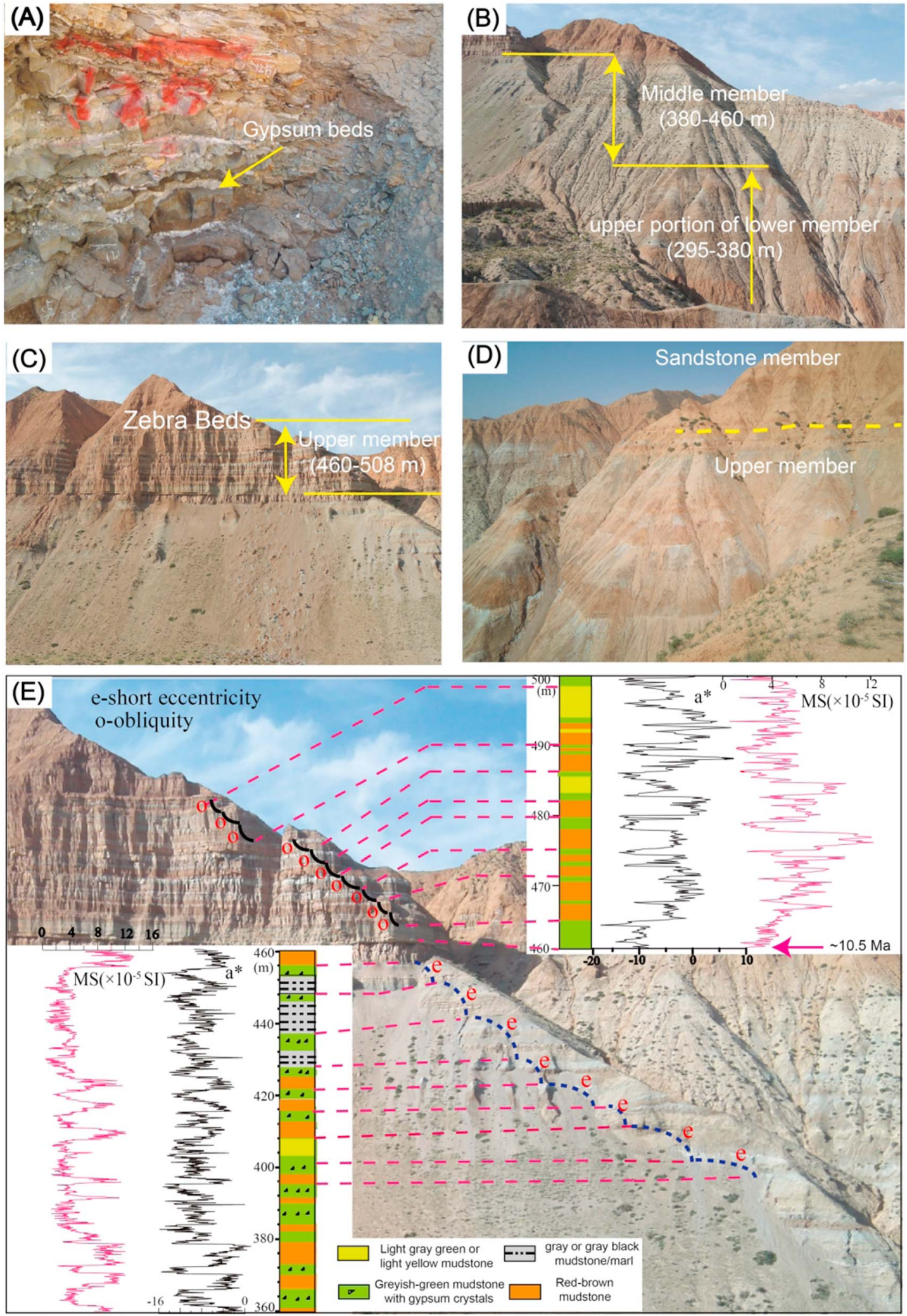

Figure 3. Pictures of different sedimentary facies described in the section. (a) Gypsum beds in the lower member (ASG section). (b) Middle member of the Ashigong Formation (ASGE section). (c) "Zebra beds," showing the alternation of reddish-brown mudstone and white/green calcareous and/or gypsiferous mudstone in the upper member (ASGE section). (d) Upper member and overlying sandstone member of the Ashigong Formation (ASGE section). (e) Middle and upper members of the Ashigong Formation combined with astronomical cycle interpretations (ASGE section). ASG = Ashigong; ASGE = Ashigong east. 


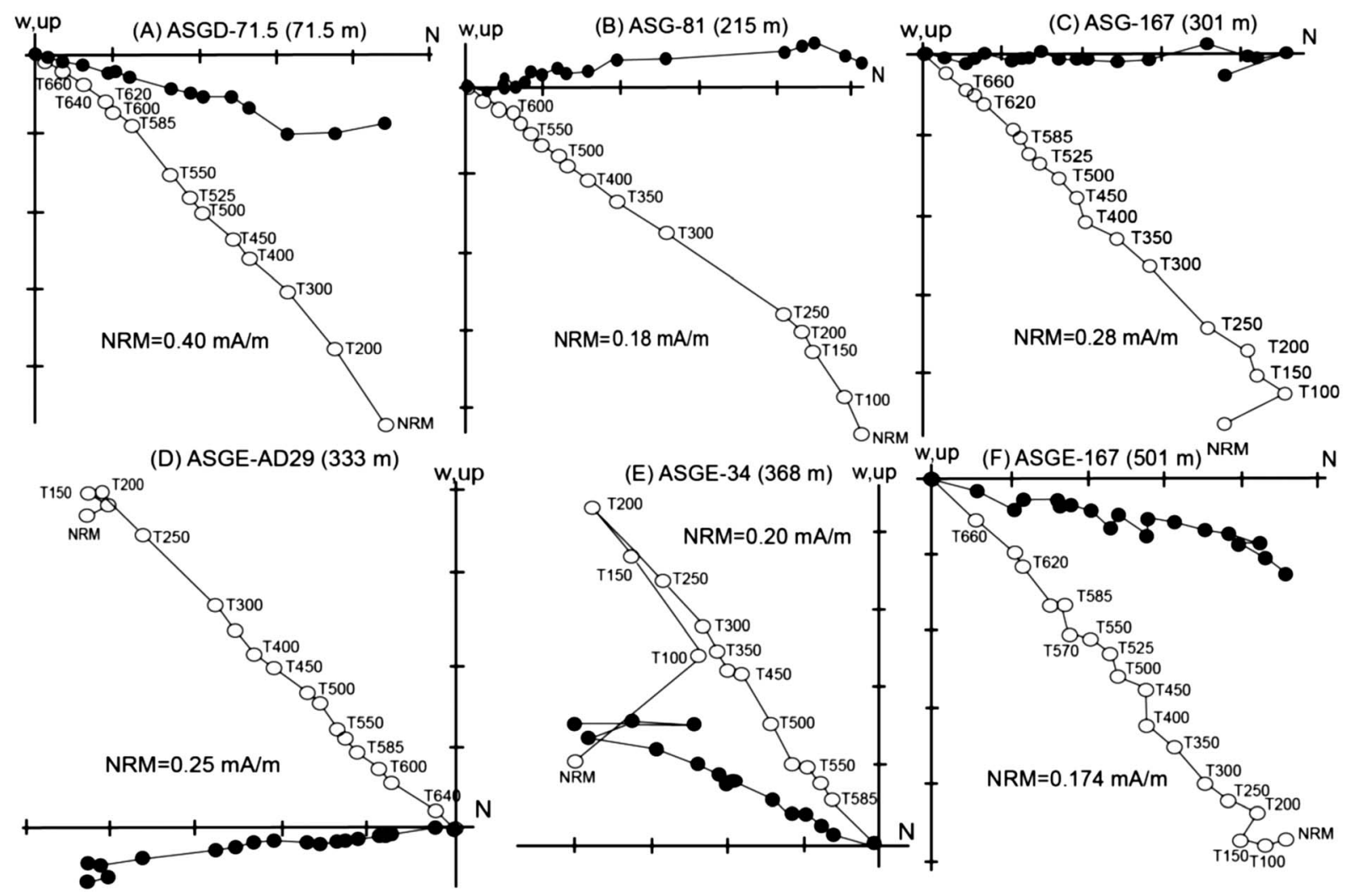

Figure 4. Orthogonal (Zijderveld) vector plots of thermal demagnetization behaviors of representative samples (a-f). The solid and open circles represent vector end points projected onto horizontal and vertical planes, respectively. NRM is the natural remanent magnetization before demagnetization. The low-temperature component is removed at $200-300^{\circ} \mathrm{C}$ and the high-temperature component is interpreted to be the characteristic remanent magnetization. ASG $=$ Ashigong; ASGE $=$ Ashigong east; $\mathrm{NRM}=$ natural remanent magnetization .

and siltstones (Figure 3c). The section is overlain by thick, coarse-grained to gravelly, cross-bedded sandstone (Figure $3 \mathrm{~d}$ ) at $>510 \mathrm{~m}$ in our composite log.

\subsection{Paleomagnetic Results}

The intensity of the natural remanent magnetization (NRM) values ranges from $10^{-4}$ to $10^{-6} \mathrm{~A} / \mathrm{m}$. Higher NRM intensity $\left(10^{-4}\right.$ to $\left.10^{-5} \mathrm{~A} / \mathrm{m}\right)$ commonly corresponds to red-brown mudstone layers. Thermal demagnetization results were analyzed with orthogonal (Zijderveld) vector plots (Figures $4 a-4 f$ ). A low-temperature component in most of the samples was removed at $300^{\circ} \mathrm{C}$ (Figure 4) accompanied by a rapid decay in intensity near $120^{\circ} \mathrm{C}$ that is probably related to the presence of goethite. A characteristic remanent magnetization (ChRM) was identified upon removing a magnetization component below $300^{\circ} \mathrm{C}$ in most cases. Significant remanence demagnetization at $\sim 585^{\circ} \mathrm{C}$ in some cases suggests that magnetite may be an important magnetic carrier (Figure 4e). However, the intensity in most samples did not reduce to the noise levels until 640-680 ${ }^{\circ} \mathrm{C}$, suggesting a combination of maghemite and hematite for the main carriers. ChRM directions were determined from at least four points from the stable high-temperature component by using principal component analysis with PaleoMag software (Jones, 2002). We discarded any sample that would display one of these features: (1) direction of ChRM remained indefinable or jumped irregularly; (2) the NRM was lower than the noise level of the Superconducting Magnetometer; (3) maximum angle deviation was greater than $15^{\circ}$; or (4) the virtual geomagnetic pole (VGP) latitude was less than $30^{\circ}$. A total of 338 samples successfully passed through this screening procedure.

The mean directions for normal- and reversed-polarity poles are $\mathrm{Dg}=358.6^{\circ}, \mathrm{lg}=43.6^{\circ}\left(\mathrm{kg}=13.8, \alpha 95=2.6^{\circ}\right)$ and $\mathrm{Dg}=175.4^{\circ}, \mathrm{lg}=-39.5^{\circ}\left(\mathrm{kg}=9.7, \alpha 95=4.9^{\circ}\right)$ in geographic coordinates and $\mathrm{Dg}=9.2^{\circ}, \lg =40.2^{\circ}$ 


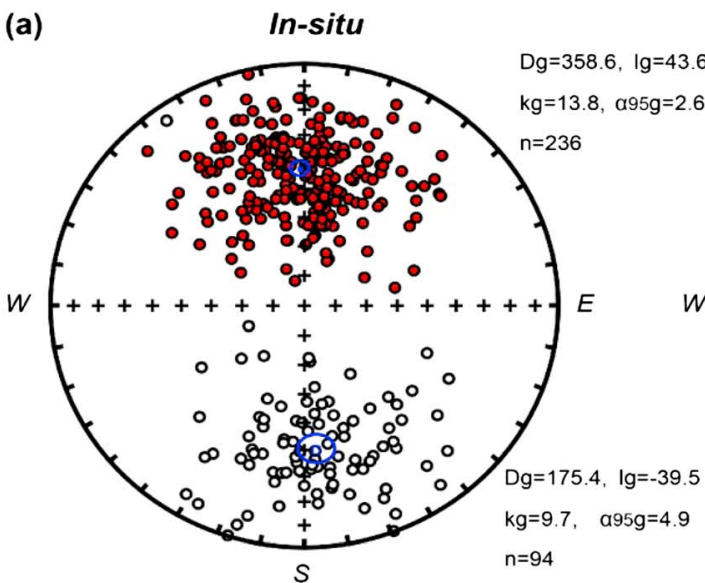

(b)

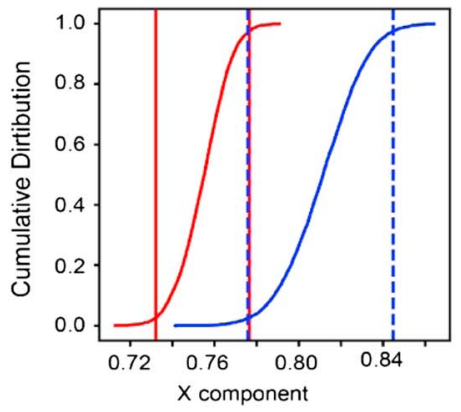

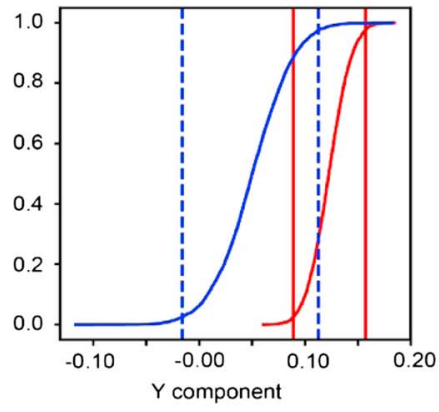

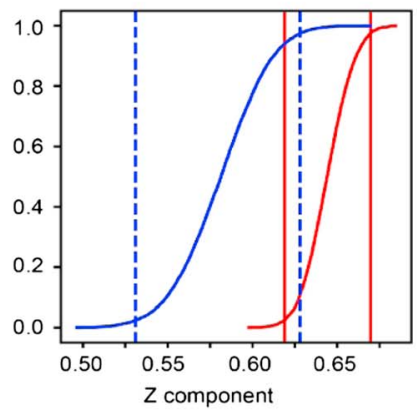

Figure 5. (a) Equal area plots of the ChRM directions in the in situ and tilt-corrected coordinates from the Ashigong section. The blue circles indicate the mean directions. (b) Bootstrap reversals test for the Ashigong Formation. The $95 \%$ confidence bounds (vertical lines) for the normal and reverse antipodes basically overlap; suggesting that the two directions are not significantly different and pass the bootstrap reversal test (Ji et al., 2017).

$\left(\mathrm{kg}=13.2, \alpha 95=2.6^{\circ}\right)$ and $\mathrm{Dg}=183.3^{\circ}, \mathrm{lg}=-36.0^{\circ}\left(\mathrm{kg}=12.1, \alpha 95=4.4^{\circ}\right)$ in tilt-corrected coordinates, (Figure 5a). However, the reversal test is negative at the $95 \%$ confidence level (McFadden \& McElhinny, 1990) due to a slight bias in the mean normal-polarity directions toward the East and of the mean reversed-polarity direction toward the West. The same bias was also reported in the paleomagnetic results from the Neogene strata in the nearby Xining Basin (Xiao et al., 2012), the Xunhua Basin (Lease et al., 2012), and Lanzhou Basin (Wang et al., 2016) and has been attributing to unremoved recent field overprint and/or tectonic rotation with time. The bootstrap reversals test in our sampling profile shows that the normal- and reversed-polarity antipodes basically overlap at the $95 \%$ confidence bounds, suggesting that our results pass the bootstrap reversal test (Tauxe, 1998; Tauxe et al., 2016; Figure 5b).

\subsection{Magnetostratigraphic Correlation}

A magnetostratigraphic scale for our section was constructed based on the virtual geomagnetic pole latitudes from the data (Figure 6). We identified nine normal (N1-N9) and eight reversed (R1-R8) polarity zones based on at least two sites determine a polarity zone. Single specimen intervals are shown in Figure 6 but not used to define polarity epochs (Figure 6).

The occurrence of the early middle Miocene fossil mammal Kubanochoerus cf. lantiensis in the underlying Garang Formation (Fang et al., 2005; Gu et al., 1992), gives a maximum 16-Ma age for the base of the Ashigong Formation. Previous discoveries of Hipparion $s p$ and Gazella gaudryi in the upper part of the Ashigong Formation, dated between 5.2 and 9 Ma (Song et al., 2001), give a minimum age for the top of our section. Based on previous paleomagnetic dating of the younger units by Fang et al. (2005), we also know that (1) the top of the Ashigong Formation is older than $\sim .8 \mathrm{Ma}$ (base of the overlying Heerjia Formation) and (2) the transition from lacustrine to fluvial deposits in the uppermost Ashigong layers is dated at 10.2 Ma. 


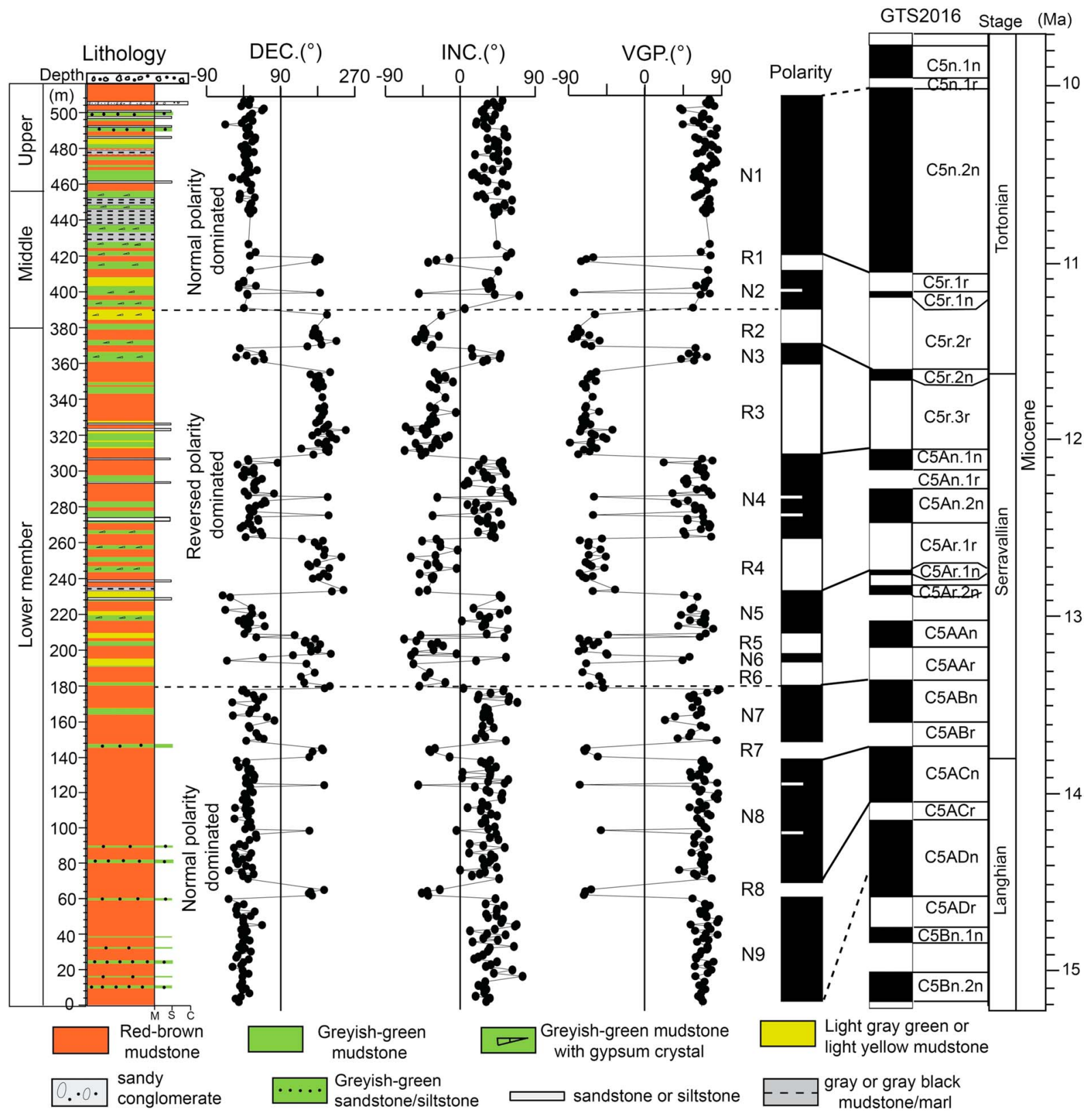

Figure 6. Magnetic polarity stratigraphy of the sampling section and its correlation to the geomagnetic polarity timescale (GTS; Ogg et al., 2016). The lithologies are shown on the left. Each polarity zone in the magnetic polarity stratigraphy is determined by at least two specimens. A single specimen is labeled with half bars. VGP $=$ virtual geomagnetic pole.

Using these two constrains, we correlated the polarity zone N1 with chron C5n.2n of GTS2016 (Ogg et al., 2016). This correlation gives an age of $\sim 10.0 \mathrm{Ma}$ for the transition from the last lacustrine layers to the coarse-grained sandstone at the top section, in close agreement with $~ 10.2-\mathrm{Ma}$ age for the cessation of lacustrine facies by Fang et al. (2005). The reversed-polarity-dominated 2-Myr span below this uppermost normal-polarity interval is consistent with the duration for the reversed-dominated set of Chrons C5AArC5r. Assuming there are no significant hiatuses, this implies that the normal polarity zones N7, N8, and N9 in the lower part of section correlate with the trio of normal-polarity-dominated Chrons C5ADn-C5Bn. Our correlation gives an age of approximately 14.5 Ma or slightly younger for the base of our section. Chron C5An.1r is the only chron that we could not unambiguously correlate with our polarity zones, suggesting a potential short $(\sim 50 \mathrm{kyr})$ sedimentary gap at that time. 
Table 1

Duration and Sedimentary Rate of Magnetozones Using Tuned $a^{*}$ Series and Comparison to Corresponding Durations of the Correlations to Neogene Magnetic Polarity Chrons (GTS2016)

\begin{tabular}{|c|c|c|c|c|}
\hline $\begin{array}{l}\text { Magnetic zones and its } \\
\text { corresponding depths }\end{array}$ & $\begin{array}{l}\text { Tuned ages with } \\
\text { uncertainty (kyr) }\end{array}$ & $\begin{array}{l}\text { Sedimentary rates based } \\
\text { on tuned age }(\mathrm{cm} / \mathrm{kyr})\end{array}$ & Paleomagnetic ages (kyr) & $\begin{array}{l}\text { Sedimentary rates based on } \\
\text { paleomagnetic age }(\mathrm{cm} / \mathrm{kyr})\end{array}$ \\
\hline $\mathrm{N} 7+\mathrm{R} 7(140-\sim 181.6 \mathrm{~m})$ & $368 \pm 52$ & $11.3 \pm 1.8$ & $\sim 350(\mathrm{C} 5 \mathrm{ABn}-\mathrm{C} 5 \mathrm{ABr})$ & 11.8 \\
\hline $\mathrm{N} 6$ + R6 (181.6- 203 m) & $145 \pm 48$ & $14.8 \pm 3.7$ & 330 (C5AAn-C5AAr) & 6.5 \\
\hline N5 + R5 (203- 232.4 m) & $292 \pm 50$ & $10 \pm 1.4$ & $\sim 300$ (C5Ar.1n-C5Ar.2r) & 9.8 \\
\hline $\mathrm{N} 4+\mathrm{R} 4(232.4-\sim 312.2 \mathrm{~m})$ & $662 \pm 60$ & $12.0 \pm 1.0$ & $\sim 650$ (C5An.1n-C5Ar.1r) & 11.4 \\
\hline $\mathrm{N} 3+\mathrm{R} 3(312.2-\sim 372.8 \mathrm{~m})$ & $475 \pm 65$ & $12.7 \pm 1.4$ & $\sim 460$ (C5r.2n-C5r.3r) & 14.4 \\
\hline $\mathrm{N} 2+\mathrm{R} 2(372.8-\sim 415 \mathrm{~m})$ & $585 \pm 57$ & $7.2 \pm 0.6$ & $\sim 630(\mathrm{C} 5 \mathrm{r} .1 \mathrm{n}-\mathrm{C} 5 \mathrm{r} .2 \mathrm{r})$ & 8.0 \\
\hline $\mathrm{N} 1+\mathrm{R} 1(415-510 \mathrm{~m})$ & $1,080 \pm 66$ & $8.8 \pm 0.5$ & $\sim 1,050$ (C5n.2n-C5r.1r) & 8.8 \\
\hline
\end{tabular}

Note. The age uncertainties are determined by the $\sim 100$-kyr band pass as well as paleomagnetic boundary uncertainties as a result of 1- to 2-m intervals in the paleomagnetic reversal. The N2, N3, and N6 + R6 (red font) have a large difference between tuned age span and the correlated magnetic polarity chrons, implying that a potential hiatus has truncated part of N6. GTS = geomagnetic polarity timescale.

This magnetostratigraphic correlation implies a 10-Ma age for the top of our section and extends the age of the base of the Ashigong Formation to at least 14.4 Ma. The composite section has an average accumulation rate of about $11.2 \mathrm{~cm} / \mathrm{kyr}$, with a higher accumulation rate in the lower part that slows to approximately $8.5 \mathrm{~cm} / \mathrm{kyr}$ for the upper part (Table 1). The average accumulation rate is consistent with previous estimates by Fang et al. (2005). The middle member, dominated by lacustrine deposits, is dated to 11.4 to $10.5 \mathrm{Ma}$.

\subsection{Redness, MS, and Elemental Content}

The evolution of redness $\left(a^{*}\right), M S$, and elemental content is strongly correlated with lithologic variations in our section (Figure 7). High values of $\mathrm{a}^{*}$ and MS correspond to red-brown mudstone layers, whereas low values correspond to grayish-green/gray black mudstone, sandstone, and siltstone layers (Figure 7). MS gradually increases in the lower member, rapidly declines and stays low in the middle member, and then slightly increases in the upper member (Figure 7a). Iron content remains relatively stable in the lower member; it then slightly decreases in the middle and upper members, together with increased amplitude variations (Figure 7b). Calcium content remains relatively stable in the lower member, and then slightly increases in the middle and upper members (Figure 7c). Strontium content is low in the lower member and significantly increases in the middle member with large amplitude changes; it then subsequently returns to its initial low values in the upper member (Figure $7 d$ ). Redness $\left(a^{*}\right)$ gradually decreases in the lower member, stays at low values in the middle member, and gradually increases in the upper member (Figure 7e).

\subsection{Spectral Analysis}

Redness evolution was divided into four parts for astronomical analysis based on the slight changes observed in accumulation rates through the section: 140-282, 280-384, 380-463, and 462-510 m (Figure 8). Each of these parts overlaps on several meters for numerical purposes to decrease boundary effects while calculating frequencies. Based on the mean accumulation rate constrained by paleomagnetic patterns and the comparison between frequency ratio of proxy and ratios of Milankovitch frequencies, the dominated $~ 13-$ and $~ 5.3-$ $\mathrm{m}$ cycles in the 140- to 282-m intervals represent $\sim 100-\mathrm{kyr}$ eccentricity and 41-kyr obliquity cycles, respectively (Figure 8a). The 280- to 384-m intervals show dominant cycles at $\sim 20 \mathrm{~m}$ and a lesser one at $\sim 7.5 \mathrm{~m}$. The $\sim 20$-m cycles are interpreted as $\sim 100-k y r$ eccentricity cycles (Figure $8 \mathrm{~b}$ ). The 380- to $463-\mathrm{m}$ interval is dominated by $\sim 6.7-\mathrm{m}$ cycles, representing $\sim 100-\mathrm{kyr}$ cycles (Figure $8 \mathrm{c}$ ). The interval of $462-510 \mathrm{~m}$ displays a different cyclic pattern with $\sim 3.5-, \sim 2.1-, \sim 1.8-$, and $\sim 1.5-\mathrm{m}$ cycles. Here the $\sim 3.5-$ and 1.5- to 2.1 -m cycles likely represent $\sim 41-\mathrm{kyr}$ obliquity and $\sim 23-\mathrm{kyr}$ precession cycles, respectively (Figure $8 \mathrm{~d}$ ). In total, we counted 35 eccentricity cycles of $\sim 100$-kyr (Figure 8). Our tuning indicates an $\sim 3.59$-myr duration for the 140- to 510-m sampling interval (Figure 9).

The tuning results show that duration times of $\mathrm{N} 1+\mathrm{R} 1, \mathrm{~N} 2+\mathrm{R} 2, \mathrm{~N} 3+\mathrm{R} 3, \mathrm{~N} 4+\mathrm{R} 4, \mathrm{~N} 5+\mathrm{R} 5, \mathrm{~N} 6+\mathrm{R} 6$, and $N 7+R 7$ are about 1,080 $\pm 66,585 \pm 57,475 \pm 65,662 \pm 60,292 \pm 50,145 \pm 48$, and $368 \pm 52$ kyr, respectively. The age uncertainties are determined by the $\sim 100-k y r$ band pass as well as paleomagnetic boundary 
(A)
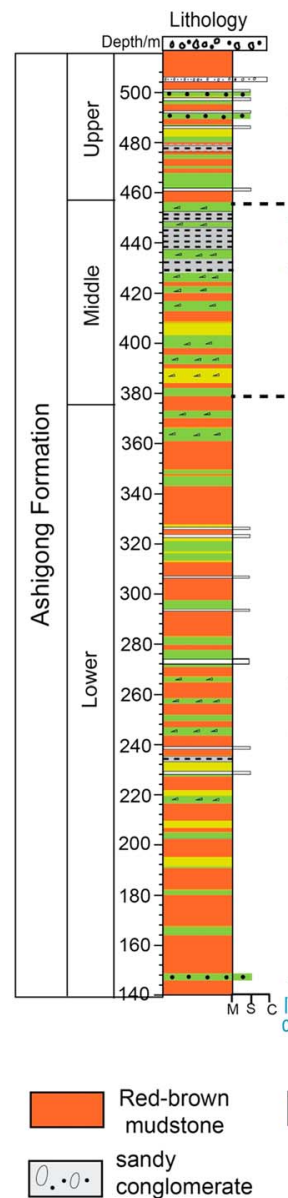

(B) $\mathrm{Fe}(\%)$ $0 \quad 2 \quad \mathrm{Fe}_{4}(\%)$
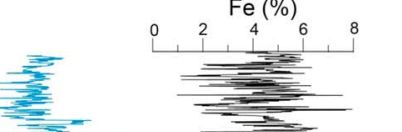

(C)

(D)

(E)

$$
\sim 13 \mathrm{~m} \sim 5.3 \mathrm{~m}
$$

व

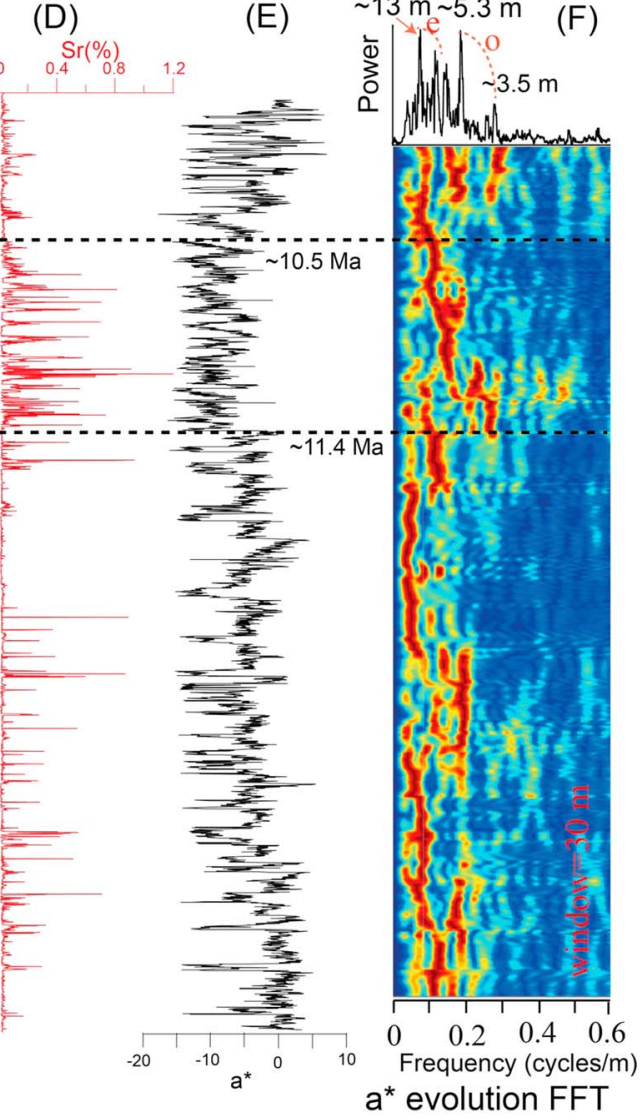

(F)

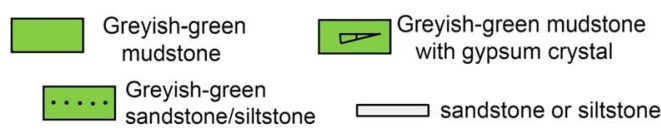
Light gray green or
light yellow mudstone

_._ gray or gray black e-eccentricity o-obliquity

Figure 7. Evolution of magnetic susceptibility (a), $\mathrm{Fe}(\mathrm{b}), \mathrm{Ca}(\mathrm{c})$, and $\mathrm{Sr}(\mathrm{d})$ content, and redness ( $\mathrm{a}^{*}$; e) in the section. The section can be divided into three parts with different values for these five proxies: $140-380,380-456$, and $456-508 \mathrm{~m}$. Grain size abbreviations: $M=$ mudstone; $S=$ sandstone/siltstone; $C=$ conglomerate. (f) Evolutive Fast Fourier transform spectrum used 30 -m sliding window shows the $a^{*}$ series in the depth domain with $2 \pi$ MultiTaper Method power spectrum of a* from 140 to $510 \mathrm{~m}$. $\mathrm{e}=$ eccentricity; o = obliquity.

uncertainties as a result of 1- to 2-m intervals in the paleomagnetic reversal. Tuned ages for the chrons in GTS2016 are overall consistent with our paleomagnetic results except for N2, N3, and N6 + R6, which are shorter in our section (Table 1). These discrepancies are likely due to small stratigraphic gaps in our section or poorer paleomagnetic results during these three intervals (Figure 6).

\section{Discussion}

\subsection{Depositional Environments}

In two previous papers, Song et al. (2001) and Fang et al. (2005) interpreted the finely laminated gray mudstones of the Ashigong Formation as reflecting the lacustrine part of a former fluvio-lacustrine system and red beds as reflecting pedogenized overbank deposits. Fine lamination and interstitial gypsum in the gray mudstones, as well as blocky structures in the red beds of our section corroborate these interpretations.

The lower and upper members are dominated by red beds and reflect a depositional environment at the margin of the paleolake, with episodic, small lake fluctuations. The middle member is dominated by gray mudstones, indicating a more permanent lake transgression. The decrease in MS and Fe content in the middle member can be linked to the decreased pedogenic development and associated oxidation. Increased $\mathrm{Ca}$ and $\mathrm{Sr}$ content in the middle member suggest increased carbonate precipitation (likely lacustrine carbonate in this case). The grayish-green mudstones and siltstones, which were deposited during high lake levels, 

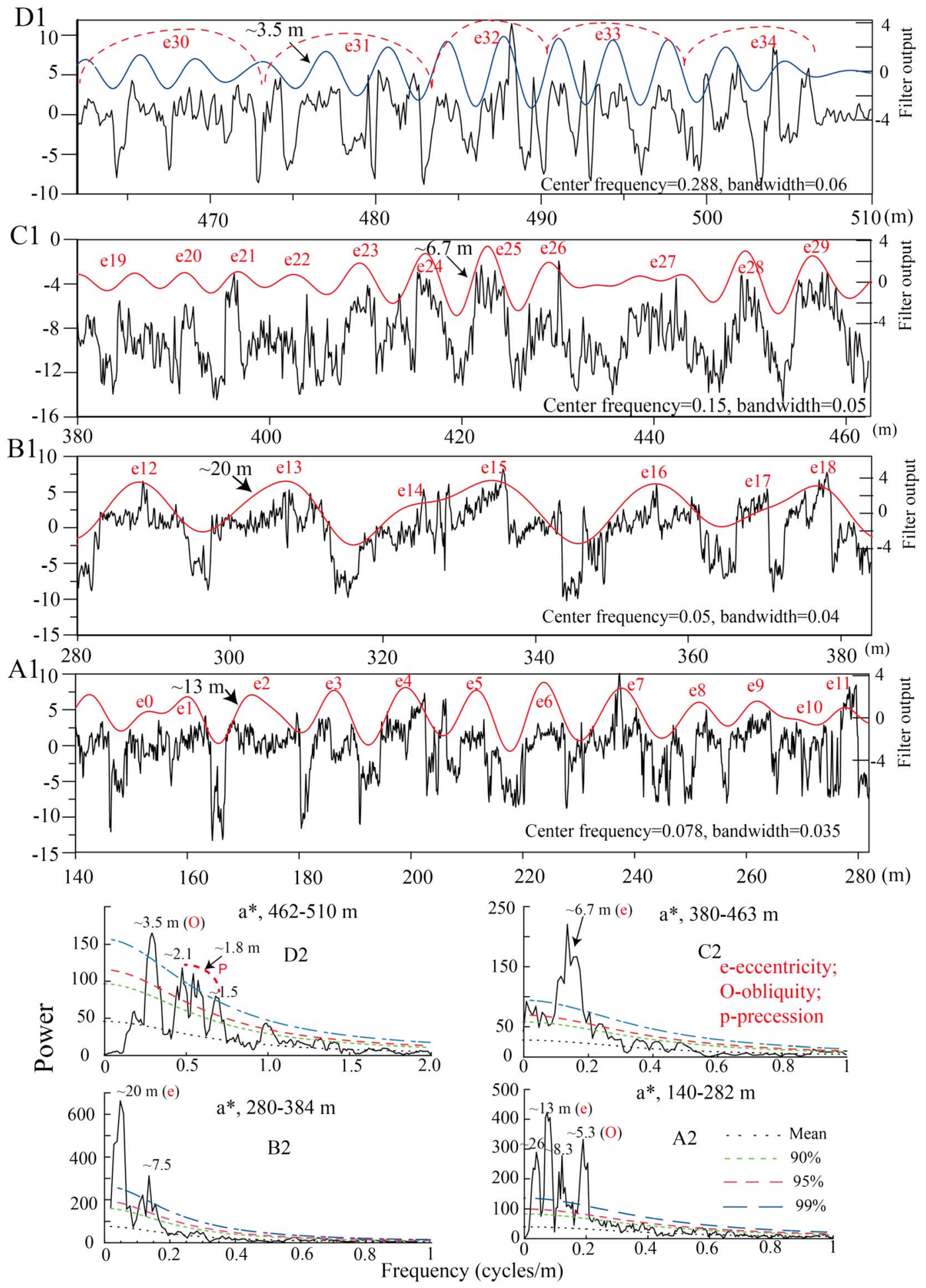

Figure 8. Results of the spectral analysis. The $\mathrm{a}^{*}$ series of $140-282$ and $280-384 \mathrm{~m}$ after subtracting a $50 \%$ weighted average and original 380-463 and 462-510 $\mathrm{m}$ after subtracting a 10\% weighted average band-pass filtered series and power spectra. A1-D1: The $\mathrm{a}^{*}$ band-pass filtered curves of $140-282 \mathrm{~m}$ at $\sim 13 \mathrm{~m}$ (red curve, $0.078 \pm 0.035$ cycles per meter), 280-384 $\mathrm{m}$ at $\sim 20 \mathrm{~m}$ (red curve, $0.05 \pm 0.04$ cycles per meter), 380-463 $\mathrm{m}$ at $\sim 6.7 \mathrm{~m}$ (red curve, $0.15 \pm 0.05$ cycles per meter), $462-510 \mathrm{~m}$ at $\sim 3.5 \mathrm{~m}$ (blue curve, $0.288 \pm 0.06$ cycles per meter) and the red dotted lines show 100-kyr eccentricity cycles, respectively. A2, B2, C2, and D2 are $2 \pi$ MultiTaper Method power spectrum of $a^{*}$ in the depth domain with robust red noise modeling, respectively. In order to decrease boundary effects while calculating frequencies, each paragraph is overlapped by several meters. 


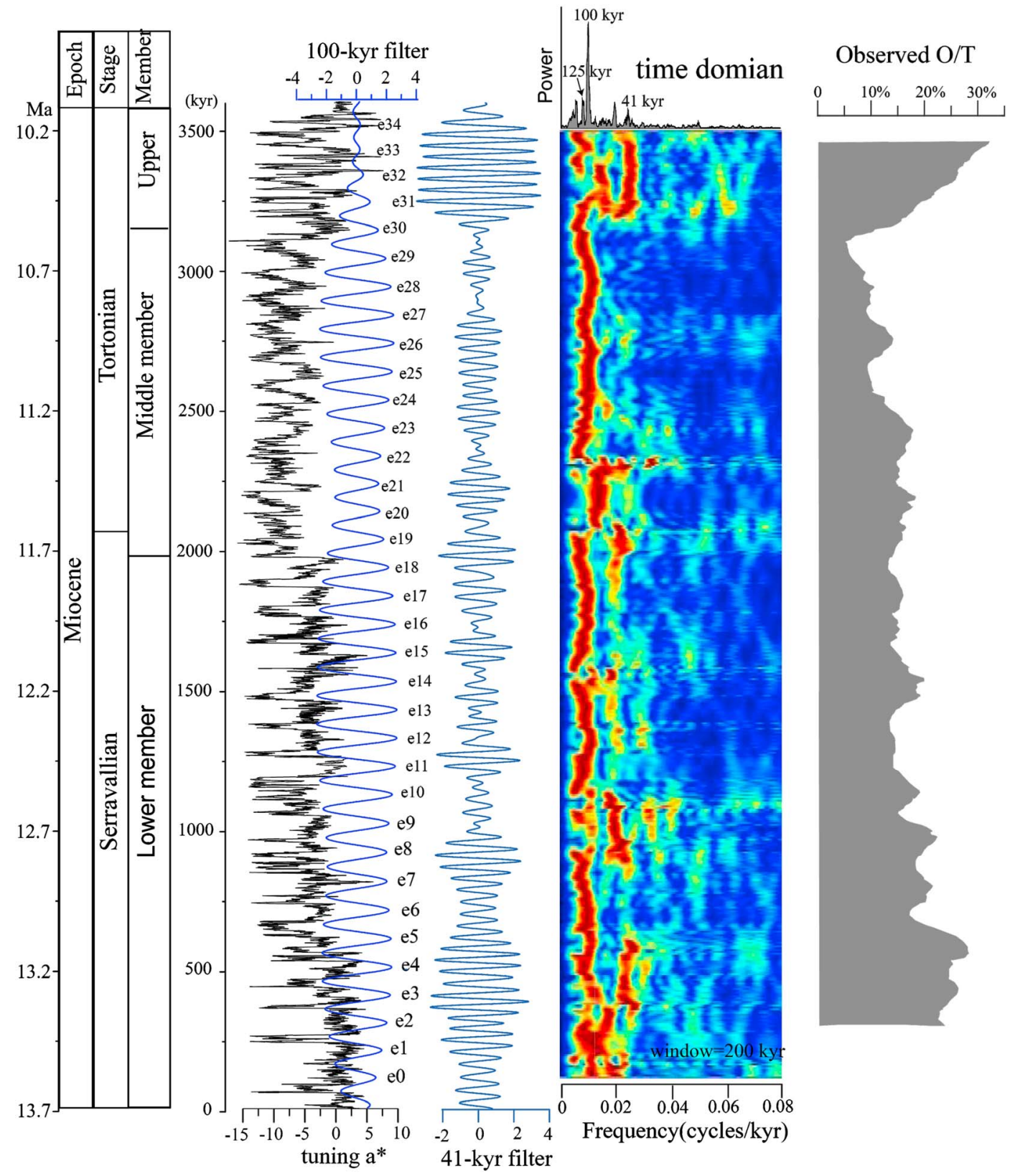

Figure 9. Cyclostratigraphic record converted into the time domain, with chronostratigraphic framework (Ogg et al., 2016) in the leftmost. The tuning a* time series (black curve), and its 100- and 41-kyr filtered curve (blue curve; Gauss filter, passband: $0.01 \pm 0.002$ cycles per kiloyear and $0.0244 \pm 0,005$ cycles per kiloyear); $2 \pi$ MultiTaper Method evolutive Fast Fourier transform using a 200-kyr sliding window shows the $a^{*}$ time series in the time domain with $2 \pi$ MultiTaper Method power spectrum. The observed $\mathrm{O} / \mathrm{T}$ shows the ratio of obliquity power to total power $(\mathrm{O} / \mathrm{T})$, which demonstrates that total power was integrated from 0 to Nyquist frequency, and detailed procedures to calculate the $\mathrm{O} / \mathrm{T}$ ratio have been presented in Li et al. (2016).

correlate to higher proportions of Sr values. Finally, the coarse sandstones overlying our section indicate a significant regression of the lacustrine system and the disappearance of lacustrine conditions. The occurrence of these sandstones at $\sim 10.0 \mathrm{Ma}$ is in agreement with the previously proposed age of $\sim 10.2 \mathrm{Ma}$ for the end of lacustrine conditions in the Ashigong Formation (Fang et al., 2005).

Of particular interest is the widespread occurrence of gypsum throughout our section in the lacustrine gray beds, which had not been described in previously. The implications are important: First, they indicate that the Ashigong paleolake was a hydrologically closed saline lake (cf. Eugster \& Hardie, 1978; Wang et al., 2013). The 
absence of gypsum in previously published sections (Fang et al., 2005) suggests that our study location was probably located in the central, deeper parts of the lacustrine system relative to other sections, where evaporites commonly occur. A more central location in the paleolake for our section also explains why the end of lacustrine conditions occurred slightly later here than the previously proposed age of $10.2 \mathrm{Ma}$.

\subsection{Basin Evolution}

Provenance and paleocurrent studies have shown that the Zamazari Shan, which isolates the Guide Basin from the Xunhua Basin to the east, had already uplifted by the early Miocene (Hough et al., 2014). Our dating of the initiation of a hydrologically closed saline lake system in the Guide Basin by at least 14.4 Ma is consistent with this early closure of the basin in response to the Zamazari Shan uplift. Interestingly, the persistence of hydrologically closed conditions until at least $10 \mathrm{Ma}$ gives a maximum age for the formation of this portion of the Upper Reach of the Yellow River (that today goes through the Guide Basin), thereby contradicting models that imply a Paleogene origin for this portion of the Yellow River (Lin et al., 2001). Lake overfilling and/or stream capture following further deformation and uplift in the late Miocene might have eventually resulted in the opening of the lake basin (Fang et al., 2005; Hough et al., 2014).

We thus propose a simple storyline for the Neogene evolution of the Guide Basin (Figure 10): The greater Guide-Xunhua-Xining-Linxia Basin developed during the Paleogene at the northern edge of the paleo-NE Tibetan plateau along the Qinling Shan. The uplift of the Zamazari Shan and Laji Shan during the early Miocene ( 22 Ma; Lease et al., 2012; Hough et al., 2014) resulted in the isolation of the Guide Basin. By at least 14.4 Ma, and potentially much earlier, the basin became fully closed and occupied by a large saline lake. The lake reached its maximum extent in the mid-Miocene between about 11.5 to $10.5 \mathrm{Ma}$. By the late Miocene, the basin drainage became open and the former lacustrine system was buried under deposits from braided rivers and alluvial fans (Fang et al., 2005). The timing of hydrological closure and of the evolution stages of the basin are similar to the histories of the neighboring Linxia and Xunhua Basins, thereby corroborating the regional character of the deformation (Hough et al., 2011).

In such a tectonically active context, interpreting the origin of the lake expansion represented by the middle member of the Ashigong Formation, at $\sim 11.4-10.5 \mathrm{Ma}$ (middle of Chron C5r to mid-C5n), is not straightforward. It is noteworthy that this period of lake expansion is coeval to other major episodes of lacustrine deposition in the nearby Xunhua, Jianzha and Linxia Basins (Hough et al., 2011, 2014). Two mechanisms may have contributed to these lacustrine phases:

1. Lake expansion could have been controlled by increased thrusting and uplift at the margin of the basins. Increased uplift could result in increased orographic effects on precipitation in the region and increase the water budget of the paleolake; alternatively, thrusting would result in increased basin subsidence and expansion of lacustrine facies (Flemings \& Jordan, 1990). There is evidence for increased uplift and thrusting further east, along the Jishi Shan in the Xunhua and Linxia Basins, which is particularly well recorded as a major change of sedimentary provenance at around 11.5 Ma in the Linxia Basin (Lease et al., 2012). However, provenance (Lease et al., 2007) and paleomagnetic (Fang et al., 2005) studies suggest that the Guide Basin was not impacted significantly by renewed uplift until $\sim 8 \mathrm{Ma}$, therefore after the deposition of the lacustrine Ashigong Formation. Moreover, the preservation of a well-marked cyclostratigraphic orbital signal in our section suggests that the area was not particularly tectonically active during this short period or that tectonics did not particularly influence accumulation rates and facies on short (a few hundreds of kiloyears) timescales.

2. Increased summer monsoonal rainfall and/or decreased lake evaporation during the 11.4- to 10.5-Ma window could explain the observed increased lake importance. It is particularly noteworthy that this time window corresponds very well to the peak of East Asian monsoonal intensity during the Neogene (Clift et al., 2008). Stable isotopes from the South China Sea indicate a remarkable warming episode at 10.8-10.7 Ma (Holbourn et al., 2013); the timing of this warming episode in the early part of Chron C $5 \mathrm{n} .2 \mathrm{n}$ is projected using our magnetostratigraphy to be at about $430-450 \mathrm{~m}$ in our composite Ashigong section (Figures $4 \mathrm{e}$ and 7 ), which fits with maximum lake expansion in our section. We thus argue that this mechanism is the most likely.

These two scenarios could potentially be further distinguished by studying lake fluctuations in the nearby basins. Phased episodes of lake transgression over entire NE Tibet would rather indicate an external, 


\section{(A) Early Miocene ( 20-15 Ma)}
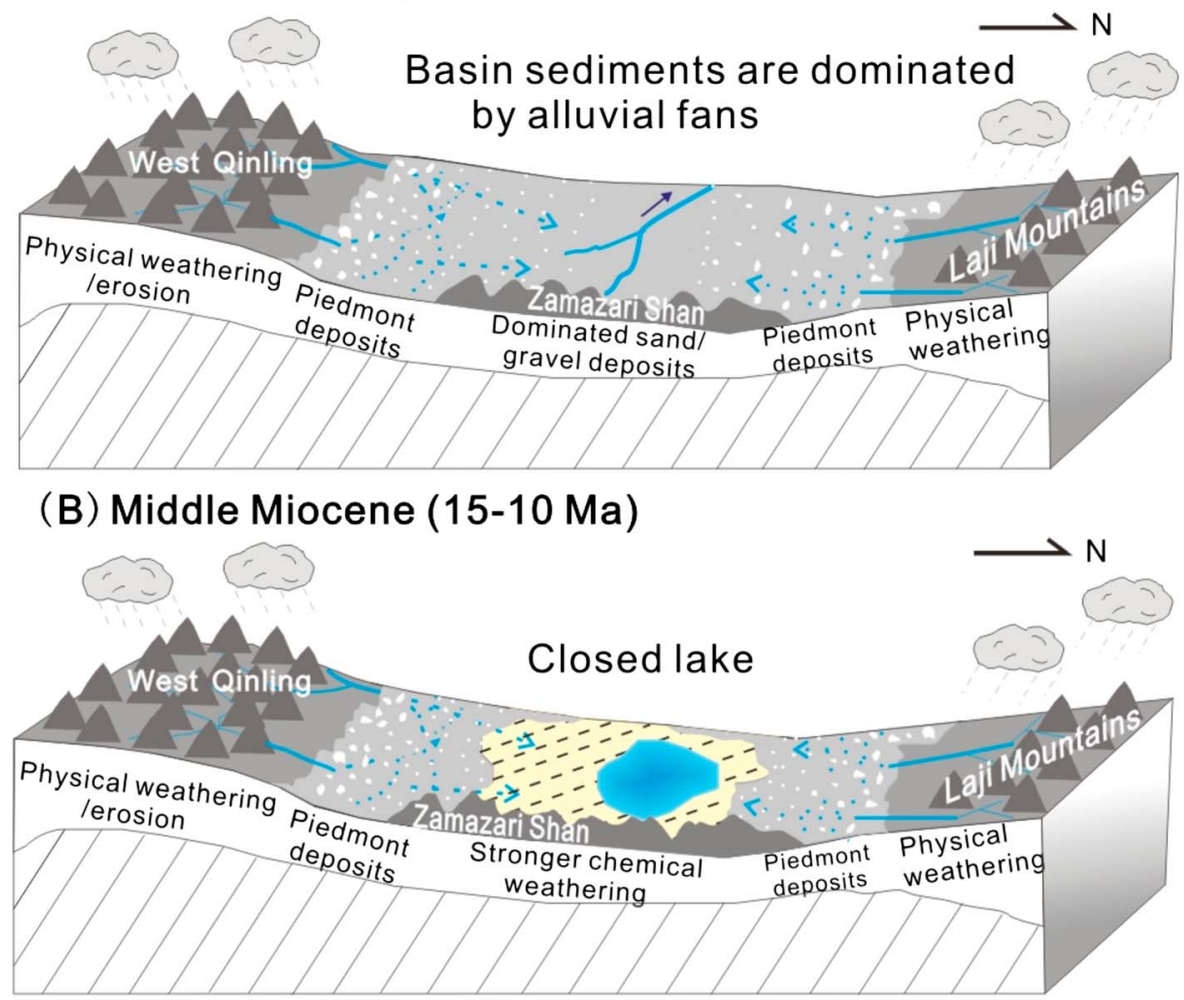

(C) Late Miocene (10-5.3 Ma)

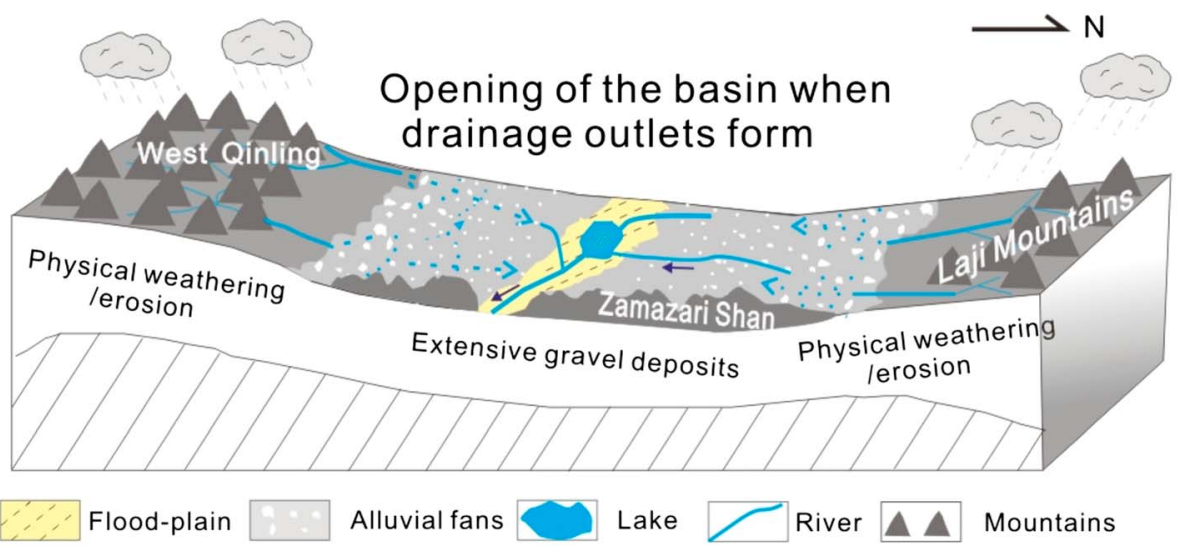

Figure 10. Schematic evolution of the Guide Basin from 20 to 5 Ma.

climatic forcing on lake expansion and favor the monsoonal trigger scenario. Preliminary dating work in the Xunhua and Linxia Basins by Hough et al. (2011) indicate periods of lacustrine deposition during this precise time interval, but lake fluctuations remain to be investigated with more details in these basins to test our scenarios.

\subsection{Significance of the Astronomical Signal in the Ashigong Formation}

In Eastern China and particularly on the Chinese Loess Plateau, late Quaternary periods of increased/reduced dust supply are commonly linked to eccentricity, whereas rainfall amount and monsoonal supply is more controlled by obliquity forcing (Li et al., 2017). The origin of this obliquity forcing has been linked to the gradient of boreal summer insolation: The influence of obliquity on summer insolation is stronger in high latitudes than in low latitudes, and periods of high gradient of boreal summer 
insolation introduce a greater contrast between the low-pressure system over central Asia and the highpressure system over the Pacific, creating stronger East Asian monsoons (Li et al., 2017). The eccentricity control on dust supply appears to be prominent in the Mio-Pliocene red clays as well (Anwar et al., 2015), but Mio-Pliocene orbital controls on moisture supply and lake expansion in eastern China are virtually undocumented.

Spectral analyses of the redness ( $\mathrm{a}^{*}$ ) series in Ashigong Formation reveals that eccentricity was the dominant control on lake expansion for the lower and middle member ( 13.5-10.5 Ma), with low-amplitude obliquity forcing involved. Eccentricity appears to have less influence on the record in the upper member, with obliquity becoming dominant control (10.5-10 Ma; Figures 3e and 9). This upper member is yet too short to allow us to make any definitive statement about the robustness of this shift.

Regardless of the robustness of the 10.5-Ma shift to obliquity in our data, our results indicate that monsoonal supply into NE Tibet was not dominantly controlled by obliquity during the late middle Miocene, at odds with known monsoonal dynamics for the Quaternary. Spectral analysis of upper Miocene lacustrine deposits in the Qaidam Basin further east period corroborates a strong 100-kyr eccentricity forcing on the hydrological budget of central China (Nie et al., 2017). These results question the climatic mechanism that could have enhanced moisture supply during this period of varying monsoonal activity (Clift et al., 2008). Nie et al. (2017) linked the dominant 100-kyr cycles to insolation-driven Antarctic ice sheet forcing on monsoonal intensity and proposed three potential mechanisms for this teleconnection: (1) periodic expansion of Antarctica ice sheets resulted in significant eustatic variations, leading to advances and retreats of East Asian coastlines (e.g., Sun et al., 2015) and impacting the availability of moisture along the pathway of East Asian summer monsoon winds. Yet the impact of these changing coastlines remain to be quantified and might be marginal. (2) Lower sea surface temperatures in the South China Sea associated with colder glacial climate would reduce evaporation and moisture availability and results in a decrease of East Asian monsoonal intensity; this mechanism is supported by evidence for a strong eccentricity forcing on sea surface temperatures in the Pacific region at that time, approximately 13.8 to $10 \mathrm{Ma}$ (Holbourn et al., 2005, 2013; Holbourn, Kuhnt, Clemens, et al., 2013). (3) Antarctica ice sheet size variation has been shown to significantly impact cross-equatorial pressure gradient and amount of latent heat release, which could have a dampening effect on monsoonal intensity (Ao et al., 2016; Clemens et al., 2008).

Interestingly, both the Qaidam and Guide Basins are on the pathway of winter westerlies, resilient winds that have been shown to be important moisture carriers in the past (Bougeois et al., 2018; Licht et al., 2016). During the late middle Miocene, times of eccentricity minima ( 100 and $400 \mathrm{kyr}$ ) are marked by shrinking of lake levels near the source of westerly derived moisture, in the Mediterranean region (Valero et al., 2014). Similarly, middle Miocene lake expansions in southeast Kazakhstan, on the westerly wind pathway, were prominently controlled by eccentricity (Voigt et al., 2017). Despite its distance to our study area $(>1,500 \mathrm{~km})$, the sedimentary record in the Aktau Mountains of Southeastern Kazakhstan displays a striking similarity with the paleolake evolution of the Guide Basin: onset of lacustrine setting at 15 Ma, maximum lake expansion at 11-10 Ma followed by lake retreat and return to fluvio-lacustrine deposition (Voigt et al., 2017). These observations suggest that lake expansions in both the Guide and Qaidam Basins might have recorded enhanced penetration of westerly derived moisture.

\section{Conclusions}

We analyzed the lithology, magnetostratigraphy, redness, MS, and elemental content of a composite section of the Ashigong Formation in the Guide Basin, NE Tibetan Plateau. Our lithologic and paleomagnetic results, coupled with cyclostratigraphy interpretations, indicate a nearly continuous deposition in a fluvio-lacustrine setting within a hydrologically closed basin between $\sim 14.4$ and $\sim 10.0 \mathrm{Ma}$. These results confirm previous evidence for an early Miocene partitioning of NE Tibetan sedimentary basins and give a maximum late middle Miocene age for the opening of the basin system and the onset of the Yellow River system. We show that lake expansions were controlled by eccentricity variations, with a maximum expansion episode between $\sim 11.4$ and $10.5 \mathrm{Ma}$. This period corresponds to a previously documented peak in monsoonal activity, suggesting a monsoonal control on lake expansion. Yet well-marked eccentricity forcing in other central Asian lakes during the Miocene suggest that varying penetration of westerly derived moisture might have also played a significant role in the lake hydrological budget. 


\section{Acknowledgments}

We thank Deng Yunkai, Li Yanzhen, Li Yanzhi, and Tian Wei for their assistance with field sampling. We also thank Ren Qiang, Li Haiyan (Chinese University of Geosciences in Beijing), Ji Junliang, Xiao Guoqiao, Zhang Rui (Chinese University of Geosciences in Wuhan), and Li Leyi (Chinese Academy of Science, Xi'an) for help in experiment. We are grateful to Jim Ogg for language editing that notably improved the manuscript. We are grateful to editor and three anonymous reviewers for their constructive reviews of this paper. This work was supported by Natural Science Foundation for Distinguished Young Scholars of Hubei Province of China (2016CFA051) and the National Natural Science Foundation of China (41772029, 41322013), the 111 Project (B14031, B08030), and 973 Program (2014CB239101) and supported by the Fundamental Research Funds for the Central Universities, China University of Geosciences (Wuhan; CUGCJ1703, CUGQYZX1705). The data supporting our conclusions can be found at https:// doi.pangaea.de/10.1594/

PANGAEA.893904.

\section{References}

Abràmoff, M. D., Magalhães, P. J., \& Ram, S. J. (2004). Image processing with ImageJ. Biophotonics International, 11(7), 36-42. An, Z., Kutzbach, J. E., Prell, W. L., \& Porter, S. C. (2001). Evolution of Asian monsoons and phased uplift of the Himalaya-Tibetan plateau since Late Miocene times. Nature, 411(6833), 62-66.

Anwar, T., Kravchinsky, V. A., \& Zhang, R. (2015). Magneto- and cyclostratigraphy in the red clay sequence: New age model and paleoclimatic implication for the eastern Chinese Loess Plateau. Journal of Geophysical Research: Solid Earth, 120, 33-48. https://doi.org/10.1002/ 2015JB012132

Ao, H., Roberts, A. P., Dekkers, M. J., Liu, X., Rohling, E. J., Shi, Z., et al. (2016). Late Miocene-Pliocene Asian monsoon intensification linked to Antarctic ice-sheet growth. Earth and Planetary Science Letters, 444, 75-87. https://doi.org/10.1016/j.epsl.2016.03.028

Bookhagen, B., Thiede, R. C., \& Strecker, M. R. (2005). Abnormal monsoon years and their control on erosion and sediment flux in the high, arid northwest Himalaya. Earth and Planetary Science Letters, 231(1-2), 131-146. https://doi.org/10.1016/j.epsl.2004.11.014

Bougeois, L., Dupont-Nivet, G., de Rafélis, M., Tindall, J. C., Proust, J. N., Reichart, G. J., et al. (2018). Asian monsoons and aridification response to Paleogene sea retreat and Neogene westerly shielding indicated by seasonality in Paratethys oysters. Earth and Planetary Science Letters, 485, 99-110. https://doi.org/10.1016/j.epsl.2017.12.036

Caves, J. K., Winnick, M. J., Graham, S. A., Sjostrom, D. J., Mulch, A., \& Chamberlain, C. P. (2015). Role of the westerlies in Central Asia climate over the Cenozoic. Earth and Planetary Science Letters, 428, 33-43. https://doi.org/10.1016/j.epsl.2015.07.023

Clark, M. K., Farley, K. A., Zheng, D., Wang, Z., \& Duvall, A. R. (2010). Early Cenozoic faulting of the northern Tibetan Plateau margin from apatite (U-Th)/He ages. Earth and Planetary Science Letters, 296(1-2), 78-88. https://doi.org/10.1016/j.epsl.2010.04.051

Clemens, S. C., Prell, W. L., Sun, Y., Liu, Z., \& Chen, G. (2008). Southern Hemisphere forcing of Pliocene $\delta^{18} \mathrm{O}$ and the evolution of Indo-Asian monsoons. Paleoceanography and Paleoclimatology, 23, PA4210. https://doi.org/10.1029/2008PA001638

Cleveland, W. S. (1979). Robust locally weighted regression and smoothing scatterplots. Journal of the American Statistical Association 74(368), 829-836. https://doi.org/10.1080/01621459.1979.10481038

Clift, P. D., Hodges, K. V., Heslop, D., Hannigan, R., Van Long, H., \& Calves, G. (2008). Correlation of Himalayan exhumation rates and Asian monsoon intensity. Nature Geoscience, 1(12), 875-880. https://doi.org/10.1038/ngeo351

Clift, P. D., Wan, S., \& Blusztajn, J. (2014). Reconstructing chemical weathering, physical erosion and monsoon intensity since $25 \mathrm{Ma}$ in the northern South China Sea: A review of competing proxies. Earth-Science Reviews, 130, 86-102. https://doi.org/10.1016/j. earscirev.2014.01.002

Eugster, H. P., \& Hardie, L. A. (1978). Saline lakes. In A. Lerman (Ed.), Lakes: Chemistry, geology, physics (pp. 237-293). New York: Springer. Fang, X., Garzione, C., Van der Voo, R., Li, J., \& Fan, M. (2003). Flexural subsidence by 29 Ma on the NE edge of Tibet from the magnetostratigraphy of Linxia Basin, China. Earth and Planetary Science Letters, 210(3-4), 545-560. https://doi.org/10.1016/S0012-821X(03)00142-0

Fang, X., Yan, M., Van der Voo, R., Rea, D. K., Song, C., Parés, J. M., et al. (2005). Late Cenozoic deformation and uplift of the NE Tibetan Plateau: Evidence from high-resolution magnetostratigraphy of the Guide Basin, Qinghai Province, China. Geological Society of America Bulletin, 117(9), 1208-1225. https://doi.org/10.1130/B25727.1

Flemings, P. B., \& Jordan, T. E. (1990). Stratigraphic modeling of foreland basins: Interpreting thrust deformation and lithosphere rheology Geology, 18(5), 430-434. https://doi.org/10.1130/0091-7613(1990)018<0430:SMOFBI >2.3.CO;2

Gu, Z., Bai, S., Zhang, X., Ma, Y., Wang, S., \& Li, B. (1992). Neogene subdivision and correlation of sediments within the Guide and Hualong basins of Qinghai province (in Chinese). Journal of Stratigraphy, 16, 96-104.

He, P., Song, C., Wang, Y., Chen, L., Chang, P., Wang, Q., \& Ren, B. (2017). Cenozoic exhumation in the Qilian Shan, northeastern Tibetan Plateau: Evidence from detrital fission track thermochronology in the Jiuquan Basin. Journal of Geophysical Research: Solid Earth, 122 6910-6927. https://doi.org/10.1002/2017JB014216

Holbourn, A., Kuhnt, W., Clemens, S., Prell, W., \& Andersen, N. (2013). Middle to late Miocene stepwise climate cooling: Evidence from a high-resolution deep water isotope curve spanning 8 million years. Paleoceanography, 28, 688-699. https://doi.org/10.1002/ 2013PA002538

Holbourn, A., Kuhnt, W., Frank, M., \& Haley, B. A. (2013). Changes in Pacific Ocean circulation following the Miocene onset of permanent Antarctic ice cover. Earth and Planetary Science Letters, 365, 38-50. https://doi.org/10.1016/j.epsl.2013.01.020

Holbourn, A., Kuhnt, W., Schulz, M., \& Erlenkeuser, H. (2005). Impacts of orbital forcing and atmospheric carbon dioxide on Miocene ice-sheet expansion. Nature, 438(7067), 483-487. https://doi.org/10.1038/nature04123

Hough, B. G., Garzione, C. N., Wang, Z., \& Lease, R. O. (2014). Timing and spatial patterns of basin segmentation and climate change in northeastern Tibet. The Geological Society of America Special Paper, 507, 129-153. https://doi.org/10.1130/2014.2507(07)

Hough, B. G., Garzione, C. N., Wang, Z., Lease, R. O., Burbank, D. W., \& Yuan, D. (2011). Stable isotope evidence for topographic growth and basin segmentation: Implications for the evolution of the NE Tibetan Plateau. Geological Society of America Bulletin, 123(1-2), 168-185. https://doi.org/10.1130/B30090.1

Hui, Z., Li, J., Xu, Q., Song, C., Zhang, J., Wu, F., \& Zhao, Z. (2011). Miocene vegetation and climatic changes reconstructed from a sporopollen record of the Tianshui Basin, NE Tibetan Plateau. Palaeogeography, Palaeoclimatology, Palaeoecology, 308(3-4), 373-382. https://doi.org/ 10.1016/j.palaeo.2011.05.043

Ji, J., Zhang, K., Clift, P. D., Zhuang, G., Song, B., Ke, X., \& Xu, Y. (2017). High-resolution magnetostratigraphic study of the Paleogene-Neogene strata in the northern Qaidam Basin: Implications for the growth of the northeastern Tibetan Plateau. Gondwana Research, 46, 141-155. https://doi.org/10.1016/j.gr.2017.02.015

Jiang, H., \& Ding, Z. (2008). A 20 Ma pollen record of East-Asian summer monsoon evolution from Guyuan, Ningxia, China. Palaeogeography, Palaeoclimatology, Palaeoecology, 265(1-2), 30-38. https://doi.org/10.1016/j.palaeo.2008.04.016

Jiang, H., Ji, J., Gao, L., Tang, Z., \& Ding, Z. (2008). Cooling-driven climate change at 12-11 Ma: Multiproxy records from a long fluviolacustrine sequence at Guyuan, Ningxia, China. Palaeogeography, Palaeoclimatology, Palaeoecology, 265(1-2), 148-158. https://doi.org/10.1016/j. palaeo.2008.05.006

Jones, C. H. (2002). User-driven integrated software lives: "Paleomag" paleomagnetics analysis on the Macintosh. Computers and Geosciences, 28(10), 1145-1151. https://doi.org/10.1016/S0098-3004(02)00032-8

Kemp, D. B., \& Coe, A. L. (2007). A nonmarine record of eccentricity forcing through the upper Triassic of southwest England and its corre lation with the Newark Basin astronomically calibrated geomagnetic polarity time scale from North America. Geology, 35(11), 991-994. https://doi.org/10.1130/G24155A.1

Kodama, K. P., \& Hinnov, L. A. (2014). Rock magnetic cyclostratigraphy. NJ: John Wiley \& Sons.

Lease, R. O. (2014). Cenozoic mountain building on the northeastern Tibetan Plateau. The Geological Society of America Special Paper, 507 115-127. https://doi.org/10.1130/2014.2507(06) 
Lease, R. O., Burbank, D. W., Clark, M. K., Farley, K. A., Zheng, D., \& Zhang, H. (2011). Middle Miocene reorganization of deformation along the northeastern Tibetan Plateau. Geology, 39(4), 359-362. https://doi.org/10.1130/G31356.1

Lease, R. O., Burbank, D. W., Gehrels, G. E., Wang, Z., \& Yuan, D. (2007). Signatures of mountain building: Detrital zircon U/Pb ages from northeastern Tibet. Geology, 35(3), 239-242. https://doi.org/10.1130/G23057A.1

Lease, R. O., Burbank, D. W., Hough, B., Wang, Z., \& Yuan, D. (2012). Pulsed Miocene range growth in northeastern Tibet: Insights from Xunhua Basin magnetostratigraphy and provenance. Geological Society of America Bulletin, 124(5-6), 657-677. https://doi.org/ 10.1130/B30524.1

Li, J., Yue, L., Pan, F., Zhang, R., Guo, L., Xi, R., \& Guo, L. (2014). Intensified aridity of the Asian interior recorded by the magnetism of red clay in Altun Shan, NE Tibetan Plateau. Palaeogeography, Palaeoclimatology, Palaeoecology, 411, 30-41. https://doi.org/10.1016/j. palaeo.2014.06.017

Li, M., Huang, C., Hinnov, L., Ogg, J., Chen, Z.-Q., \& Zhang, Y. (2016). Obliquity-forced climate during the Early Triassic hothouse in China Geology, 44(8), 623-626. https://doi.org/10.1130/G37970.1

Li, M., Ogg, J., Zhang, Y., Huang, C., Hinnov, L., Chen, Z.-Q., \& Zou, Z. (2016). Astronomical tuning of the end-Permian extinction and the Early Triassic Epoch of South China and Germany. Earth and Planetary Science Letters, 441, 10-25. https://doi.org/10.1016/j. epsl.2016.02.017

Li, T., Liu, F., Abels, H. A., You, C.-F., Zhang, Z., Chen, J., et al. (2017). Continued obliquity pacing of East Asian summer precipitation after the mid-Pleistocene transition. Earth and Planetary Science Letters, 457, 181-190. https://doi.org/10.1016/j.epsl.2016.09.045

Licht, A., Dupont-Nivet, G., Pullen, A., Kapp, P., Abels, H. A., Lai, Z., et al. (2016). Resilience of the Asian atmospheric circulation shown by Paleogene dust provenance. Nature Communications, 7, 12390. https://doi.org/10.1038/ncomms12390

Lin, A., Yang, Z., Sun, Z., \& Yang, T. (2001). How and when did the Yellow River develop its square bend? Geology, 29(10), 951-954. https://doi. org/10.1130/0091-7613(2001)029<0951:HAWDTY>2.0.CO;2

Liu, J., Li, J. J., Song, C. H., Yu, H., Peng, T. J., Hui, Z. C., \& Ye, X. Y. (2016). Palynological evidence for late Miocene stepwise aridification on the northeastern Tibetan Plateau. Climate of the Past, 12(7), 1473-1484. https://doi.org/10.5194/cp-12-1473-2016

Liu, S., Zhang, G., Pan, F., Zhang, H., Wang, P., Wang, K., \& Wang, Y. (2013). Timing of Xunhua and guide basin development and growth of the northeastern Tibetan Plateau, China. Basin Research, 25(1), 74-96. https://doi.org/10.1111/j.1365-2117.2012.00548.x

Liu, S. F., Zhang, G. W., \& Heller, P. L. (2007). Cenozoic basin development and its indication of plateau growth in the Xunhua-Guide district [J]. Science in China Series D: Earth Sciences, 50(S2), 277-291. https://doi.org/10.1007/s11430-007-6012-3

Liu, X., Sun, H., Miao, Y., Dong, B., \& Yin, Z.-Y. (2015). Impacts of uplift of northern Tibetan plateau and formation of Asian inland deserts on regional climate and environment. Quaternary Science Reviews, 116, 1-14. https://doi.org/10.1016/j.quascirev.2015.03.010

Mann, M. E., \& Lees, J. M. (1996). Robust estimation of background noise and signal detection in climatic time series. Climatic Change, 33(3), 409-445. https://doi.org/10.1007/BF00142586

McFadden, P. L., \& McElhinny, M. W. (1990). Classification of the reversal test in palaeomagnetism. Geophysical Journal of the Royal Astronomical Society, 103(3), 725-729. https://doi.org/10.1111/j.1365-246X.1990.tb05683.x

Miao, Y., Fang, X., Herrmann, M., Wu, F., Zhang, Y., \& Liu, D. (2011). Miocene pollen record of KC-1 core in the Qaidam Basin, NE Tibetan Plateau and implications for evolution of the east Asian monsoon. Palaeogeography, Palaeoclimatology, Palaeoecology, 299(1-2), 30-38. https://doi.org/10.1016/j.palaeo.2010.10.026

Miao, Y., Herrmann, M., Wu, F., Yan, X., \& Yang, S. (2012). What controlled Mid-Late Miocene long-term aridification in Central Asia?-Global cooling or Tibetan Plateau uplift: A review. Earth-Science Reviews, 112(3-4), 155-172. https://doi.org/10.1016/j.earscirev.2012.02.003

Miao, Y., Jin, H., Liu, B., \& Wang, Y. (2014). Natural ecosystem response and recovery after the 8.2 ka cold event: Evidence from slope sediments on the northeastern Tibetan Plateau. Journal of Arid Environments, 104, 17-22. https://doi.org/10.1016/j.jaridenv.2014.01.021

Nie, J., Garzione, C., Su, Q., Liu, Q., Zhang, R., Heslop, D., et al. (2017). Dominant 100,000-year precipitation cyclicity in a late Miocene lake from Northeast Tibet. Science Advances, 3, e1600762. https://doi.org/10.1126/sciadv.1600762

Ogg, J., Ogg, G., \& Gradstein, F. (2016). A Concise Geologic TimeScale, 2016, 203-210.

Paillard, D., Labeyrie, L., \& Yiou, P. (1996). Macintosh program performs time-series analysis. Eos, Transactions American Geophysical Union, 77(39), 379-379. https://doi.org/10.1029/96EO00259

Pares, J. M., Van-der-voo, R., Downs, W. R., Yan, M., \& Fang, X. (2003). Northeastward growth and uplift of the Tibetan Plateau: Magnetostratigraphic insights from the Guide Basin. Journal of Geophysical Research, 108(B8), 2400. https://doi.org/10.1029/ 2003JB002624

Song, C., Hu, S., Han, W., Zhang, T., Fang, X., Gao, J., \& Wu, F. (2014). Middle Miocene to earliest Pliocene sedimentological and geochemical records of climate change in the western Qaidam Basin on the NE Tibetan Plateau. Palaeogeography, Palaeoclimatology, Palaeoecology, 395, 67-76. https://doi.org/10.1016/j.palaeo.2013.12.022

Song, C. H., Fang, X. M., Gao, J. P., Sun, D., \& Fan, M. J. (2001). Cenozoic tectonic uplift and sedimentary evolution of the Guide Basin in the northeast margin of the Tibetan Plateau (in Chinese). Sedimentology, 19(4), 498-506.

Sun, J., \& Windley, B. F. (2015). Onset of aridification by 34 Ma across the Eocene-Oligocene transition in Central Asia. Geology, 43(11), 1015-1018. https://doi.org/10.1130/G37165.1

Sun, Y., Kutzbach, J., An, Z., Clemens, S., Liu, Z., Liu, W., et al. (2015). Astronomical and glacial forcing of East Asian summer monsoon variability. Quaternary Science Reviews, 115, 132-142. https://doi.org/10.1016/j.quascirev.2015.03.009

Tang, H., Micheels, A., Eronen, J. T., Ahrens, B., \& Fortelius, M. (2013). Asynchronous responses of East Asian and Indian summer monsoons to mountain uplift shown by regional climate modelling experiments. Climate Dynamics, 40(5-6), 1531-1549. https://doi.org/10.1007/ s00382-012-1603-x

Tang, Z., Ding, Z., White, P. D., Dong, X., Ji, J., Jiang, H., et al. (2011). Late Cenozoic central Asian drying inferred from a palynological record from the northern Tian Shan. Earth and Planetary Science Letters, 302(3-4), 439-447. https://doi.org/10.1016/j.epsl.2010.12.042

Tauxe, L. (1998). Paleomagnetic principles and practice (p. 299). New York: Kluwer Academic. Publishers.

Tauxe, L., Shaar, R., Jonestrask, L., Swanson-Hysell, N. L., Minnett, R., Koppers, A. A. P., et al. (2016). PmagPy: Software package for paleomagnetic data analysis and a bridge to the Magnetics Information Consortium (MaglC) database. Geochemistry, Geophysics, Geosystems, 17, 2450-2463. https://doi.org/10.1002/2016GC006307

Tian, L., Yao, T., MacClune, K., White, J. W. C., Schilla, A., Vaughn, B., et al. (2007). Stable isotopic variations in west China: A consideration of moisture sources. Journal of Geophysical Research, 112, D10112. https://doi.org/10.1029/2006JD007718

Tripati, A. K., Roberts, C. D., \& Eagle, R. A. (2009). Coupling of $\mathrm{CO}_{2}$ and ice sheet stability over major climate transitions of the last 20 million years. Science, 326(5958), 1394-1397. https://doi.org/10.1126/science.1178296

Valero, L., Garcés, M., Cabrera, L., Costa, E., \& Sáez, A. (2014). 20 Myr of eccentricity paced lacustrine cycles in the Cenozoic Ebro Basin. Earth and Planetary Science Letters, 408, 183-193. https://doi.org/10.1016/j.epsl.2014.10.007 
Voigt, S., Weber, Y., Frisch, K., Bartenstein, A., Hellwig, A., Petschick, R., et al. (2017). Climatically forced moisture supply, sediment flux and pedogenesis in Miocene mudflat deposits of south-east Kazakhstan, Central Asia. The Depositional Record, 3(2), 209-232. https://doi.org/ 10.1002/dep2.34

Wan, S., Clift, P. D., Li, A., Li, T., \& Yin, X. (2010). Geochemical records in the South China Sea: Implications for East Asian summer monsoon evolution over the last 20 Ma. Geological Society, London, Special Publications, 342(1), 245-263. https://doi.org/10.1144/SP342.14

Wang, D., Lu, S., Han, S., Sun, X., \& Quan, C. (2013). Eocene prevalence of monsoon-like climate over eastern China reflected by hydrological dynamics. Journal of Asian Earth Sciences, 62, 776-787. https://doi.org/10.1016/j.jseaes.2012.11.032

Wang, W., Zhang, P., Liu, C., Zheng, D., Yu, J., Zheng, W., et al. (2016). Pulsed growth of the west Qinling at 30 Ma in northeastern Tibet: Evidence from Lanzhou Basin magnetostratigraphy and provenance. Journal of Geophysical Research: Solid Earth, 121, 7754-7774. https:// doi.org/10.1002/2016JB013279

Wang, X., Song, C., Zattin, M., He, P., Song, A., Li, J., \& Wang, Q. (2016). Cenozoic pulsed deformation history of northeastern Tibetan Plateau reconstructed from fission-track thermochronology. Tectonophysics, 672-673, 212-227. https://doi.org/10.1016/j.tecto.2016.02.006

Wang, Z. X., Liang, M. Y., Sun, Y. Q., \& Dai, G. W. (2017). Cenozoic tectonic and geomorphic evolution of the Longxi region in northeastern Tibetan Plateau interpreted from detrital zircon. Science China: Earth Sciences, 60(2), 1-12.

Xiao, G., Guo, Z., Dupont-Nivet, G., Lu, H., Wu, N., Ge, J., et al. (2012). Evidence for northeastern Tibetan Plateau uplift between 25 and 20 Ma in the sedimentary archive of the Xining Basin, Northwestern China. Earth and Planetary Science Letters, 317-318, 185-195. https://doi.org/ 10.1016/j.epsl.2011.11.008

Xiao, G. Q., Abels, H. A., Yao, Z. Q., Dupont-Nivet, G., \& Hilgen, F. J. (2010). Asian aridification linked to the first step of the Eocene-Oligocene climate transition (EOT) in obliquity-dominated terrestrial records (Xining Basin, China). Climate of the Past, 6(4), 501-513. https://doi.org/ 10.5194/cp-6-501-2010

Zhang, Z., Flatøy, F., Wang, H., Bethke, I., Bentsen, M., \& Guo, Z. (2012). Early Eocene Asian climate dominated by desert and steppe with limited monsoons. Journal of Asian Earth Sciences, 44, 24-35. https://doi.org/10.1016/j.jseaes.2011.05.013

Zhuang, G., Hourigan, J. K., Koch, P. L., Ritts, B. D., \& Kent-Corson, M. L. (2011). Isotopic constraints on intensified aridity in Central Asia around 12 Ma. Earth and Planetary Science Letters, 312(1-2), 152-163. https://doi.org/10.1016/j.epsl.2011.10.005 